\title{
Deciphering the Role of Stay-Green Trait to Mitigate Terminal Heat Stress in Bread Wheat
}

\author{
Sadia Latif ${ }^{1,2}$, Liping Wang ${ }^{3}$, Jahangir Khan ${ }^{3}$, Zeshan Ali ${ }^{4}$, Sunish Kumar Sehgal ${ }^{5}$, \\ Md Ali Babar ${ }^{3}$, Jianping Wang ${ }^{3}$ and Umar Masood Quraishi ${ }^{1, * \mathbb{D}}$ \\ 1 Department of Plant Sciences, Quaid-i-Azam University, Islamabad 45320, Pakistan; slatif@bs.qau.edu.pk \\ 2 Department of Biology and Environmental Science, Allama Iqbal Open University, Islamabad 44000, Pakistan \\ 3 Department of Agronomy, University of Florida, Gainesville, FL 32611, USA; lwang2@ufl.edu (L.W.); \\ Jkazrc@ufl.edu (J.K.); mababar@ufl.edu (M.A.B.); wangjp@ufl.edu (J.W.) \\ 4 Plant Physiology Program, Crop Sciences Institute, National Agricultural Research Centre, \\ Islamabad 45500, Pakistan; eco4nd@yahoo.com \\ 5 Department of Agronomy, Horticulture and Plant Science, South Dakota State University, \\ Brookings, SD 57007-1096, USA; sunish.sehgal@sdstate.edu \\ * Correspondence: umasood@qau.edu.pk; Tel.: +92-336-050-6675
}

Received: 10 June 2020; Accepted: 9 July 2020; Published: 11 July 2020

check for updates

\begin{abstract}
The present study aimed to reveal the impact of the stay-green trait in bread wheat under terminal heat stress. Field experiments (early and late sowing; for two consecutive years) were conducted to investigate the influence of terminal heat stress on the morpho-physiological traits in different stay-green types i.e., non-stay-green, moderately non-stay-green, moderately stay-green, and stay-green. In addition, the greenhouse experiment was performed to dissect the stay-green trait in functional stay-green, non-functional stay-green, and non-stay-green genotypes. The results of the field experiments confirmed that genotypes exhibiting the stay-green trait have a significantly high chlorophyll content, normalized difference vegetative index, grain yield, biological yield, kernel weight, and low canopy temperature under control and heat stress conditions. In the greenhouse experiment, functional stay-green and non-functional stay-green genotypes showed a high chlorophyll content and photochemical efficiency, whereas biological yield and grain yield showed a significant relation with the functional stay-green genotype under control and terminal heat stress treatments. The sequencing and expression analysis of chlorophyllide a oxygenase $(\mathrm{CaO})$, light-harvesting complex (Cab), stay-green (SGR), and red chlorophyll catabolite reductase (RCCR) in functional stay-green, non-functional stay-green, and non-stay-green genotypes revealed variations in the exons of $\mathrm{CaO}$ and RCCR; and significant difference in the regulation of $\mathrm{CaO}$ and $\mathrm{Cab}$ at 7 days after anthesis under terminal heat stress. This study confirms that genotypes displaying the stay-green trait can aid wheat breeders to cope with increasing temperature in the impending decades.
\end{abstract}

Keywords: Triticum aestivum L.; terminal heat stress; stay green; chlorophyllide a oxygenase gene; light-harvesting complex gene; stay-green gene; red chlorophyll catabolite reductase gene

\section{Introduction}

Agriculture and climate change are internally correlated, as climate change is the main cause of biotic and abiotic stresses. Agriculture is being affected by climate changes in different ways e.g., variations in global atmospheric $\mathrm{CO}_{2}$ levels, changes in average temperature, heat waves, annual rainfall, and modifications in microbes, pest, or weeds [1-3]. Escalating global temperature together with intense and frequent heat episodes is of rising concern to global food security $[4,5]$. High temperature adversely affects the yield potential of crops by influencing its metabolic pathways 
and yield losses may reach up to $40 \%$ under severe heat stress during grain filling duration $[6,7]$. Increasing crop productivity together with the reduction in the environmental footprint is a daunting task if we want to achieve the "Zero hunger sustainable developmental goal" [8]. Cereal crops are considered as the ultimate custodian of global food security. Among cereals, the golden ears of bread wheat have been considered as a symbol of global food security since the dawn of civilization. Wheat production, with decreasing land and water resources in variable climatic conditions, needs to be increased by $60 \%$ to reach the required $\sim 840$ million tonnes by 2050 [9].

High temperature stress during the grain-filling period of the plant life cycle is termed as terminal heat stress. During the grain-filling duration, a $1{ }^{\circ} \mathrm{C}$ rise in temperature above $15^{\circ} \mathrm{C}$ is estimated to reduce the wheat yield by $6 \%[10,11]$. Heat stress causes oxidative damage which induces lipid peroxidation, protein degradation, enzyme inactivation, the instability of thylakoid membranes, decrease in chlorophyll content, and reduced rubisco activity [12,13]. It also elevates transpiration rate, the $\mathrm{pH}$ of leaf sap, and abscissic acid production that leads to premature leaf senescence [14]. These changes in the plant physiological mechanism result in reduced starch accumulation, days to maturity, thousand kernel weight, altered grain starch lipid composition, and shriveled grains [15]. Plants have evolved different mechanisms to cope with heat stress such as escape, avoidance, and stay green [16]. The stay-green trait has been considered as an indicator of high temperature stress tolerance by decelerating plant growth cycle and increasing plant productivity $[17,18]$.

Stay green, referred to as "heritable delayed foliar senescence" [19], is broadly classified into functional and non-functional stay-green. In functional stay-green, the retention of chlorophyll is coupled with the increased photosynthetic capacity and yield potential of plants in contrast to the non-functional stay-green type. Functional stay green is divided into type A (senescence is initiated late) and type B (progression of senescence is slow), whereas non-functional stay green is further classified into type C (cosmetic type), type D (pseudo stay green), and type E (hyper green) $[19,20]$. The stay-green trait has been documented in maize, oat, rice, arabidopsis, soyabean, sorghum, wheat, and other plants species [21-28]. The genetic basis behind stay green is complex and varies in different plant species. Various studies indicated the involvement of a multi-protein complex comprising of chlorophyll catabolic enzymes, stay-green protein, and light-harvesting complex protein [29]. The first two components of the multi-protein complex i.e., chlorophyll catabolic enzymes and stay-green protein, are linked with the chlorophyll degradation pathway. Chlorophyll catabolism is a multistep process that initiates with the conversion of chlorophyll $b$ to 7-hydroxymethyl chlorophyll a in the presence of chlorophyll $b$ reductase. The 7-hydroxymethyl chlorophyll $a$ is converted into chlorophyll a and the reaction is catalyzed by 7-hydroxymethyl chlorophyll a reductase [30]. Chlorophyll a degrades to pheophorbide a using magnesium dechelatase and pheophytinase, which removes the central magnesium atom and breaks the phytol side chain [31-33]. Then, pheophorbide a is catalyzed into primary fluorescent chlorophyll catabolite by the action of pheophorbide a oxygenase and red chlorophyll catabolite reductase [34]. Primary fluorescent chlorophyll catabolite is transferred from chloroplast to vacuole where it is converted into non-fluorescent chlorophyll catabolite [35]. Mutations in the chlorophyll catabolic enzyme genes can result in a stay-green phenotype by delaying the foliar senescence $[19,36]$. The light-harvesting complex protein, the third element of the multi-protein complex, accounts for approximately half of the total chlorophyll involved in photosynthesis [37-40]. The current study focused on the chlorophyllide a oxygenase $(\mathrm{CaO})$, light-harvesting chlorophyll a/b binding protein (Cab), stay-green (SGR), and red chlorophyll catabolite reductase (RCCR) genes.

The $\mathrm{CaO}$ gene is involved in the synthesis of chlorophyll $\mathrm{b}$ from chlorophyll a by the oxidation of a methyl group to a formyl group [41-44]. The over expression of the $\mathrm{CaO}$ gene results in an enhanced chlorophyll b content, changed chlorophyll a/b ratio, increased light-harvesting chlorophyll protein, boosted light capture, and the electron transport of photosystem I and II [45]. The Cab harvests photons that are converted into biochemical energy and biomass during photosynthesis. The Cab genes are down-regulated under abiotic and biotic stresses [46-49]. However, a high expression level has been observed in the tolerant genotypes [46,47]. The SGR also called the non-yellowing (NYE1) gene encodes 
for magnesium dechelatase, which catalyzes the conversion of chlorophyll a into pheophytin a [31,32]. The up-regulation of SGR results in chlorophyll degradation by reducing the number of lamellae in the grana thylakoids [50]. The RCCR, also known as accelerated cell death 2 (ACD2), catalyzes red chlorophyll catabolite to primary fluorescence chlorophyll catabolite [51,52]. The RCCR mutants accumulate red chlorophyll catabolite, which induces the production of reactive oxygen species and causes cell death $[53,54]$. The up-regulation of the RCCR gene is connected with defense responses under abiotic and biotic stresses [53-58].

The stay-green trait seems to improve grain yield under high temperature stress by retaining chlorophyll content, improving photosynthetic capacity, and extending the grain-filling period $[18,59,60]$. The precise mechanism behind the stay-green trait as an adaptive trait to heat stress still needs to be explored. The present study aimed to examine the association of the stay-green trait with the chlorophyll content, photochemical efficiency, normalized difference vegetative index (NDVI), canopy temperature, grain yield, biological yield, kernel weight, the expression profile of chlorophyll catabolism pathway genes (CaO, SGR, and RCCR), and the photosynthetic responsive gene (Cab) in bread wheat under terminal heat stress. Furthermore, it is the pioneer study that unraveled the $\mathrm{CaO}$, SGR, and RCCR gene expression in relation to the stay-green trait in Triticum aestivum under high temperature stress.

\section{Materials and Methods}

\subsection{Phenotyping}

\subsubsection{Field Experiment}

The diversity panel consisting of 123 bread wheat genotypes including landraces, green revolution cultivars, post-green revolution cultivars, elite genotypes, and synthetic derivatives was subjected to field trials (Table S1). The field experiments were performed for two consecutive years (2014-2015 and 2015 -2016) with early and late sowing to investigate the impact of heat stress. Planting was done on November 15 and December 31 each year in alpha lattice design at the National Agricultural Research Centre, Islamabad, located between $33.6701^{\circ} \mathrm{N}$ latitude and $73.1261^{\circ} \mathrm{E}$ longitude. The field experiments consisted of four rows of $1 \mathrm{~m}$ per plot for each genotype, with a sowing density of 20 seeds per row. The fertilizers were applied during land preparation using standard agricultural procedures and the irrigation regime was practiced to ensure the crop growth without water limitation. The evaluated traits were chlorophyll content, normalized difference vegetative index (NDVI), canopy temperature $(\mathrm{CT})$, plant height $(\mathrm{PH})$, tiller number (Til No), spike length (SL), spikelet per spike (SpS), days to maturity (DM), biological yield (BY), grain yield (GY), and thousand kernel weight (TKW). All the morpho-physiological traits were determined using standard protocols as described by Pask et al. [61].

The chlorophyll content was measured at booting, heading, anthesis, seven days after anthesis (7DAA), 14 days after anthesis (14DAA), and 21 days after anthesis (21DAA) using the Chlorophyll Meter (SPAD-502) in flag leaves. The normalized difference vegetative index (NDVI) was recorded at heading, anthesis, 14DAA, and 21DAA using the Trimble handheld Green-seeker. An Infrared Thermometer (Telatemp AG-42) was used to record canopy temperature at heading, anthesis, 14DAA, and 21DAA. The chlorophyll content and NDVI were measured between 11:30 a.m. and 2:00 p.m. and the canopy temperature was recorded between 1:00 p.m. and 2: 00 p.m. on windless and cloudless day. $\mathrm{PH}(\mathrm{cm})$ was determined at maturity by measuring individual culms from the soil surface to the tip of the spike excluding awn, using a meter rod. Fertile tillers per plant were recorded at the flowering stage. SL $(\mathrm{cm})$ was measured from the base of the rachis to the tip of the terminal spikelet excluding awn using a meter rod. SpS was recorded by counting the total number of spikelets from the base to the tip of the spike. Chlorophyll content, PH, Til No, SL, and SpS were measured in three replicates. DM was recorded when more than $50 \%$ of the plants per plot exhibited a loss of complete greenness. All the above-ground biomass excluding borders was harvested, dried, and weighed to determine the BY $(\mathrm{g})$. The harvested above-ground biomass was threshed and weighed to obtain the GY (g). 
The thousand kernel weight was determined by weighing 200 seeds and multiplying the obtained weight with 5 .

\subsubsection{Greenhouse Experiment}

The greenhouse experiment was conducted to dissect the stay-green trait in functional stay-green (Nepal-38), non-functional stay-green (SG-30), and non-stay-green (Sonalika) genotypes under controlled greenhouse conditions at South Dakota State University, USA. The genotypes were selected on the basis of morpho-physiological traits evaluated during the field experiments (Nepal-38 and SG-30 showed maximum values for chlorophyll content, NDVI, and days to maturity compared to Sonalika whereas, SG-30 showed shriveled grains under control conditions). The sterilized seeds of the selected genotypes were grown in the pots filled with Metro-mix ${ }^{\circledR} 360$ soil mixture and each pot contained four plants. The experiment was laid out in a completely randomized design with six biological replicates. During the experiment, the greenhouse conditions were maintained at $24 / 18{ }^{\circ} \mathrm{C}$ day/night temperatures with a photoperiod of $12 \mathrm{~h}$. Half plants of each genotype at anthesis were transferred to a growth chamber for heat stress treatment at $36 / 28{ }^{\circ} \mathrm{C}$ day/night temperatures. The pots were well watered throughout the experiment and a teaspoon of Osmocote (15N-9P-12K) was applied at tilling and booting.

The leaf chlorophyll content and photosynthetic efficiency of photosystem II (ØII) were determined using the Chlorophyll Meter (SPAD-502) and the handheld MutispeQ, respectively. Both the chlorophyll content and ØII were measured at anthesis, 7DAA, and 14DAA from the flag leaf between 12 p.m. and 2 p.m. using six replicates. The chlorophyll content for each sample was determined from three parts of the same flag leaf and the average was recorded. The ØII was measured using the photosynQ application via a global plant census project according to the manufacturer's protocol. The biological yield and grain yield per plant were determined using three biological replicates. The plant above ground biomass was harvested, dried, and weighed to obtain the biological yield per plant. After threshing, the grain harvest per plant was weighed to obtain the grain yield per plant.

\subsection{Genotyping}

\subsubsection{Sample Preparation}

The leaf samples were harvested at anthesis, 7DAA, and 14DAA from both the control and heat-treated samples in triplicate. The samples were washed with distilled water, incised with a sharp blade, immediately shifted to liquid nitrogen, and stored at $-80{ }^{\circ} \mathrm{C}$ to prevent any degradation. Leaf tissues were freeze dried for $48 \mathrm{~h}$ using FreeZone Freeze Dryer System by Labconco. The lyophilized leaf tissues were ground into fine powder using tissuelyser. The sequencing and expression analysis were performed at the Plant Molecular and Cellular Biology Laboratory, University of Florida, USA.

\subsubsection{DNA Extraction and Gel Electrophoresis}

Total genomic DNA was isolated from $20 \mathrm{mg}$ of the lyophilized leaf tissues using MagJET Plant Genomic DNA Kit by Thermo Scientific, following the manufacturer's protocol. To confirm the presence of DNA, the isolated DNA $(4 \mu \mathrm{L})$ was mixed with $6 \mathrm{X}$ loading dye $(2 \mu \mathrm{L})$ and resolved on $1 \%$ agarose gel. The gel was viewed using a gel documentation system (Bio-Rad).

\subsubsection{Identification of $\mathrm{CaO}, \mathrm{Cab}$, SGR, and RCCR Genes in the Wheat Genome}

For sequence accession in Triticum aestivum, the gene, cDNA, and protein sequences of the orthologous and phylogenetically closely related species i.e., Brachypodium distachyon, Hordeum vulgare, Sorghum bicolor, Oryza sativa, and Zea mays were used. The gene, cDNA, and protein sequences of $\mathrm{CaO}$, $\mathrm{Cab}, \mathrm{SGR}$, and RCCR in reference species were obtained from the National Center for Biotechnology Information (NCBI). The complete coding sequence of each gene from the reference species was blasted in Ensembl Plants against Triticum aestivum to obtain the genes, cDNA, and protein sequences in 
Triticum aestivum (Table S2). Sequence homologies between the cDNA and the protein sequences of Triticum aestivum, Brachypodium distachyon, Hordeum vulgare, Sorghum bicolor, Oryza sativa, and Zea mays were determined by multiple sequence alignment using the Clustal Omega tool.

\subsubsection{Phylogenetic Analysis}

Molecular evolutionary genetics analysis (Mega 6.06) was used for phylogenetic analysis [62]. The neighbor-joining method employing the p-distance and boot-strap with 1,000 replicates was used to compute the phylogenetic tree using amino acid sequences [63].

\subsubsection{Primer Designing}

The primers were designed using Primer3 plus (Table S3). The primers were checked for hairpin structure, self or heterodimer formation using Integrated DNA Technology.

\subsubsection{Amplification and Sequencing}

The $\mathrm{CaO}, \mathrm{Cab}$, SGR, and RCCR genes were amplified in functional stay-green, non-functional stay-green, and non-stay-green genotypes using the primers listed in Table S3. The reaction cocktail was prepared using $10 \mu \mathrm{L}$ of Go TAQ Master Mix, $1 \mu \mathrm{L}$ of primer forward, $1 \mu \mathrm{L}$ of primer reverse, $1.5 \mu \mathrm{L}$ of DNA template, and $6.5 \mu \mathrm{L}$ of PCR water. The PCR profile used was; $95{ }^{\circ} \mathrm{C}$ for $4 \mathrm{~min}$, followed by 40 cycles of $95{ }^{\circ} \mathrm{C}$ for $45 \mathrm{~s}, 56-62{ }^{\circ} \mathrm{C}$ for $30 \mathrm{~s}, 72{ }^{\circ} \mathrm{C}$ for $1 \mathrm{~min}$, and the final extension at $72{ }^{\circ} \mathrm{C}$ for $10 \mathrm{~min}$. The amplified PCR products were sent for sequencing to the Genomic Centre, University of Florida. The sequences were subjected to multiple sequences alignment using CLUSTALW to reveal variations.

\subsubsection{RNA Extraction, Gel Electrophoresis, and Qubit Assay}

Total RNA was extracted from the lyophilized leaf samples $(200 \mathrm{mg})$ using the plant RNA reagent (Trizol by Ambion, Life Technologies) followed by treatment with Qiagen on column DNaseI (RNeasay Mini Kit, Part 2, QIAGEN) according to the manufacturer's protocol. RNA integrity was confirmed using 1.5\% formaldehyde agarose, gel stained with ethidium bromide. The quantification of RNA was done using a Qubit RNA assay following the Qubit RNA BR Assay kit protocol.

\subsection{8. cDNA Synthesis and Quantification}

First strand cDNA was synthesized by the reverse transcription of $3 \mu \mathrm{g}$ of the RNA template in the presence of a random hexamer primer $(50 \mathrm{ng})$, deoxyribonucleotide triphosphates dNTPs $(10 \mathrm{mM})$, 10X reverse transcriptase buffer $(2 \mu \mathrm{L}), \mathrm{MgCl} 2(100 \mathrm{mM})$, dithiothreitol DDT (0.2 M), RNase (40 U), and superscript III reverse transcriptase (200 U). The total reaction volume for each sample was $20 \mu \mathrm{L}$. The standard reaction conditions as described in Superscript III First Strand Synthesis System for RT-PCR were followed (Invitrogen, Life Technologies). The cDNA was quantified by a Qubit 2.0 Fluorometer using the DsDNA feature.

\subsubsection{Transcript Abundance by Reverse Transcription Quantitative PCR (RT-qPCR)}

Real-time quantitative PCR was performed in a total reaction volume of $25 \mu \mathrm{L}$ for each sample, containing $12.5 \mu \mathrm{L}$ SYBR Green PCR Master Mix (Applied Biosystems, 4309155), $1 \mu \mathrm{L}$ of cDNA $(5 \mathrm{ng} / \mu \mathrm{L}), 1.25 \mu \mathrm{L}$ each primer forward and reverse, and $9 \mu \mathrm{L}$ PCR water using the BIO-RAD CFX Connect Real time PCR system. The standard real time PCR profile by SYBR Green PCR Master Mix, Applied Biosystems, was used, which included polymerase activation at $95{ }^{\circ} \mathrm{C}$ for $10 \mathrm{~min}$ followed by 40 cycles of denaturation at $95{ }^{\circ} \mathrm{C}$ for $30 \mathrm{~s}$ and annealing at $60{ }^{\circ} \mathrm{C}$ for $1 \mathrm{~min}$. The melt curve temperature was from $65^{\circ} \mathrm{C}$ to $95^{\circ} \mathrm{C}$. 
Amplification efficiency was determined for each primer pair using ten-fold cDNA dilution series in triplicate $(n=3)$. The threshold cycle $(C T)$ values of ten-fold cDNA dilution series were plotted to obtain the slope using linear regression. The efficiency was calculated using the following formulas:

$$
\text { Efficiency }=10^{-(1 / \text { slope })}
$$

$$
\text { Percentage Efficiency }=(E-1) \times 100
$$

For expression profiling, the CT values were normalized using the ACTIN2 gene [64] expression as

$$
\begin{gathered}
\Delta \mathrm{CT}(\text { Control })=\mathrm{CT}(\text { Control })-\mathrm{CT}(\text { Reference gene }) \\
\Delta \mathrm{CT}(\text { Treated })=\mathrm{CT}(\text { Treated })-\mathrm{CT}(\text { Reference gene })
\end{gathered}
$$

In the second step, the value of the $\Delta \mathrm{CT}$ control was subtracted from the $\Delta \mathrm{CT}$ stress and the relative expression levels were determined using 2- $\Delta \Delta C$ T Livak's method [65]. The log2 fold change was determined to demonstrate the up-regulation or down-regulation of the gene transcript.

\subsection{Statistical Analysis}

Heatmap for NDVI was developed by ClustalVis, a tool to visualize the clusters of multivariate data. The analysis of variance (ANOVA) for the phenotypic and expression profiling data was performed using XLSTAT Version 2014.5.03 by Tukey's honest significant difference (HSD) test to determine the effect of treatments on groups.

\section{Results}

\subsection{Phenotyping}

\subsubsection{Field Experiment}

The germplasm was categorized into non-stay-green, moderately non-stay-green, moderately stay-green, and stay-green groups on the basis of the NDVI. This rating scale was developed considering the mean NDVI values at heading, anthesis, 14DAA, and 21DAA together with a time point at which the NDVI decline was initiated. The genotypes showing a mean NDVI of $0.40->0.495,0.495->0.55$, $0.55->0.605$, and $0.605-0.66$ were classified into non-stay-green, moderately non-stay-green, moderately stay-green, and stay-green groups, respectively. The majority of the genotypes were classified as moderately non-stay-green $(30.9 \%)$ followed by moderately stay-green $(27.6 \%)$, stay-green $(26.8 \%)$, and non-stay-green groups (14.7\%) (Figure 1).

\section{Physiological Traits}

The chlorophyll content measured at booting, heading, anthesis, 7DAA, 14DAA, and 21DAA showed a significant decline among all the groups under heat stress condition. The chlorophyll content greatly varied between the groups at day 14 and day 21 after anthesis under the control; and at day 7 , day 14, and 21 after anthesis under high temperature stress (Figure 2, Table S4).

The NDVI at heading, anthesis, 14DAA, and 21DAA declined among all the groups under terminal heat stress. Significant variation was observed between groups and treatments for the NDVI at all time points. The stay-green group showed maximum values for the NDVI at all time points under control and heat stress conditions (Figure 3, Table S4).

The CT was recorded at heading, anthesis, 14DAA, and 21DAA. CT increased under heat stress conditions among all the groups, except for the non-stay-green and moderately non-stay-green groups at 14DAA. CT revealed significant variations among the groups and treatments at all time points. The stay-green group and non-stay-green group showed minimum and maximum mean values, respectively, at all the time points (Figure 4, Table S4). 


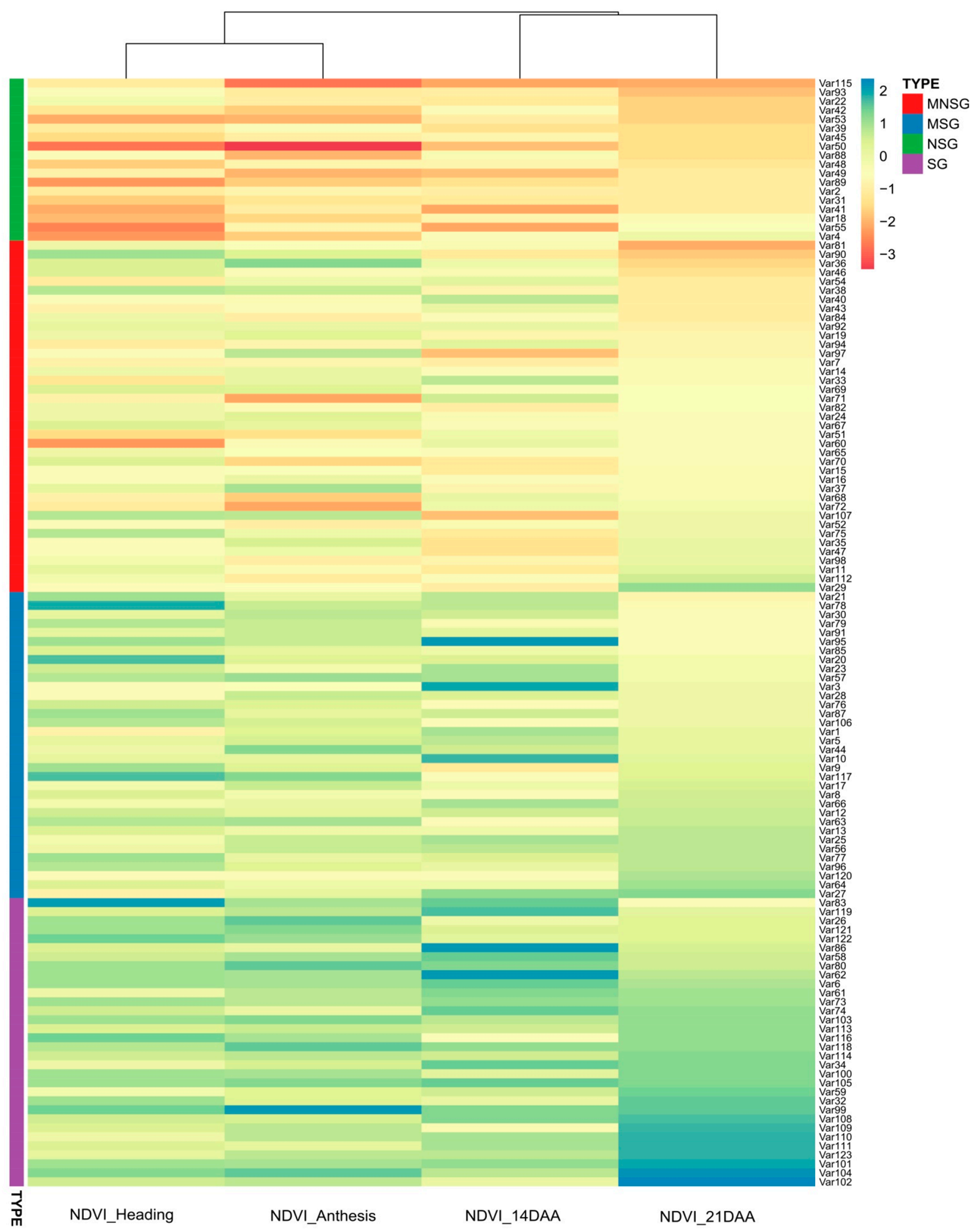

Figure 1. Heatmap depicting the normalized difference vegetative index (NDVI) in the non-stay-green (NSG), moderately non-stay-green (MNSG), moderately stay-green (MSG), and stay-green (SG) genotypes at different developmental stages under control condition. The blue color represents the maximum value for the NDVI and the red color indicates the minimum value for the NDVI. 

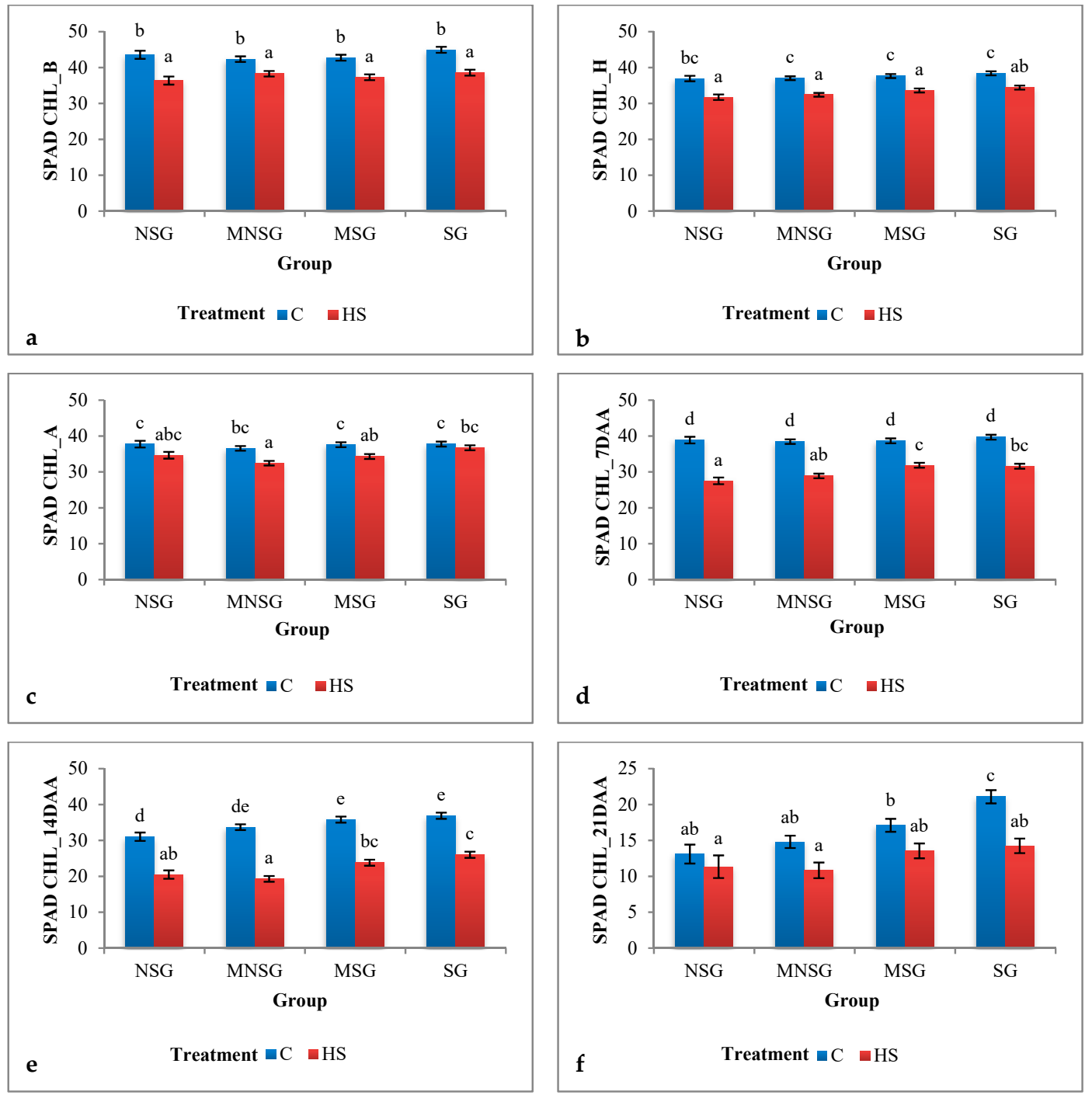

Figure 2. Chlorophyll content (CHL) in the non-stay-green (NSG), moderately non-stay-green (MNSG), moderately stay-green (MSG), and stay-green (SG) groups under control (C) and heat stress (HS) conditions. (a) Chlorophyll content at booting; (b) chlorophyll content at heading; (c) chlorophyll content at anthesis; (d) chlorophyll content at seven days after anthesis (7DAA); (e) chlorophyll content at 14 days after anthesis (14DAA); and (f) chlorophyll content at 21 days after anthesis (21DAA). Bars represent the least square means from the 2014-2015 and 2015-2016 field trails. Error bars depict the standard errors and different lowercase letters denote the significant differences among the groups and treatments at $p<0.05$. 

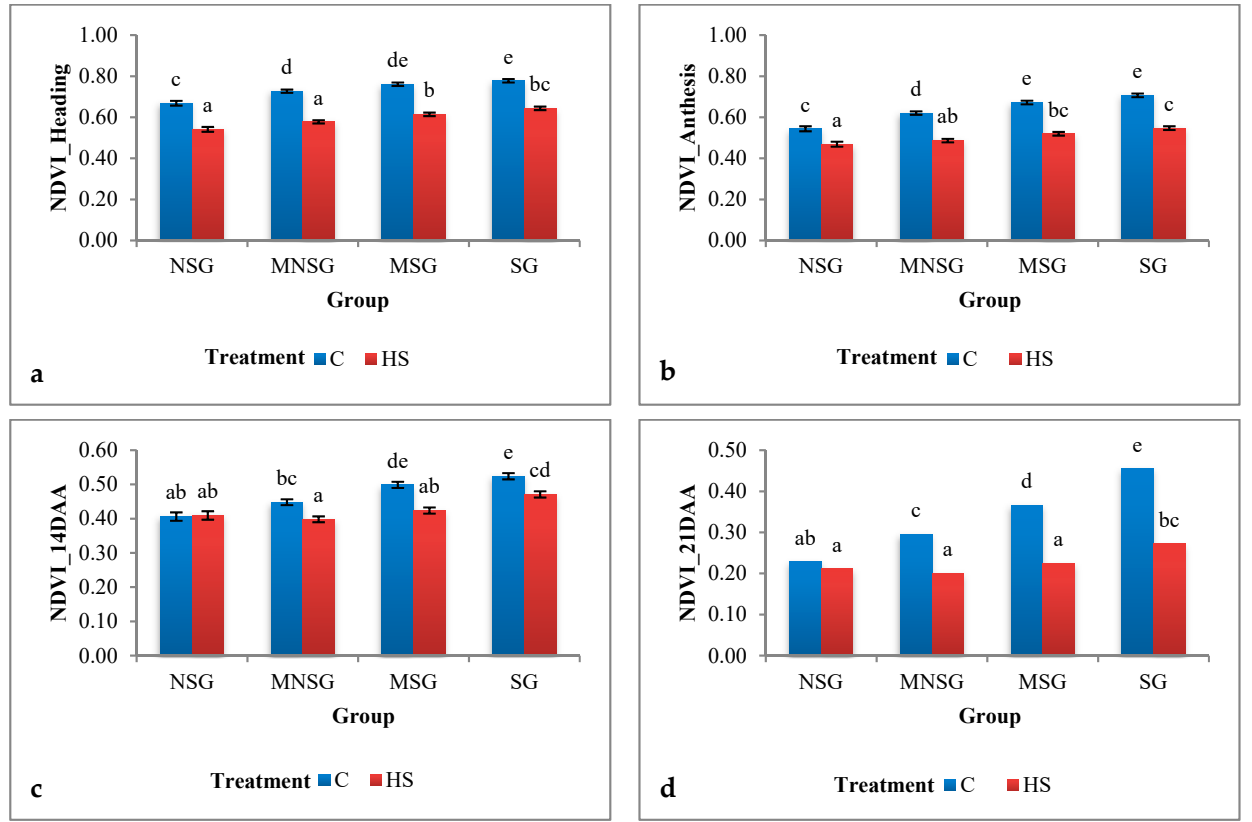

Figure 3. Variation in the normalized difference vegetative index (NDVI) between the non-stay-green (NSG), moderately non-stay-green (MNSG), moderately stay-green (MSG), and stay-green (SG) groups under control (C) and heat stress (HS) conditions. (a) NDVI at heading; (b) NDVI at anthesis; (c) NDVI after 14 days of anthesis; and (d) NDVI after 21 days of anthesis. Bars represent the least square means. Error bars correspond to the standard errors and the different lowercase letters signify the significant differences among the types and treatments at $p<0.05$.
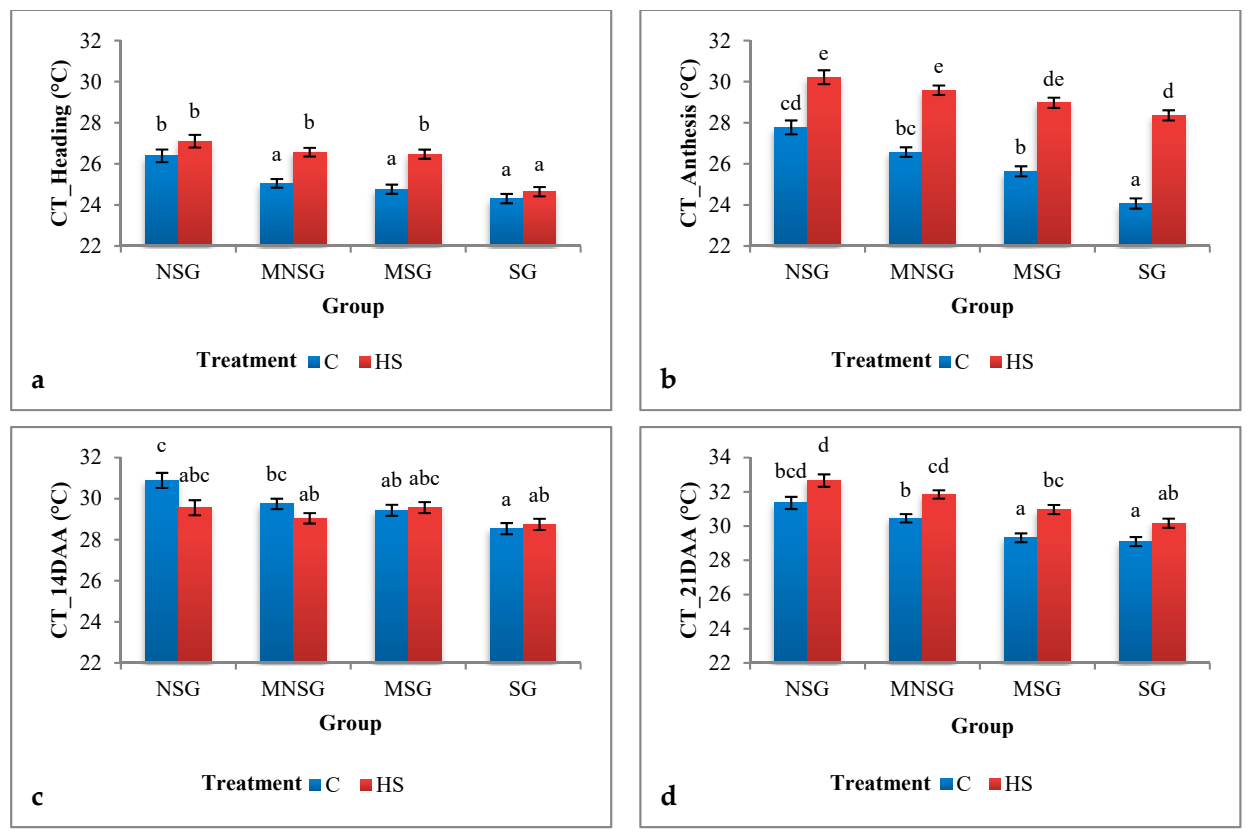

Figure 4. Variation in the canopy temperature (CT) among the non-stay-green (NSG), moderately non-stay-green (MNSG), moderately stay-green (MSG), and stay-green (SG) groups under control (C) and heat stress (HS) conditions. (a) Canopy temperature at heading; (b) canopy temperature at anthesis; (c) canopy temperature after 14 days of anthesis; and (d) canopy temperature after 21 days of anthesis. Bars represent the least square means. Error bars signify the standard errors and the different lowercase letters represent the significant differences among the groups and treatments at $p<0.05$. 


\section{Morphological Traits}

The PH, Til No, SL, SpS, DM, GY, BY, and the TKW significantly declined under heat stress conditions among all the groups. The Til No, SpS, GY, BY, and the TKW depicted significant difference among the groups. The maximum mean values for the Til No, SL, SpS, BY, GY, and the TKW were observed in the stay-green group under control and heat stress conditions (Figure 5, Table S4).
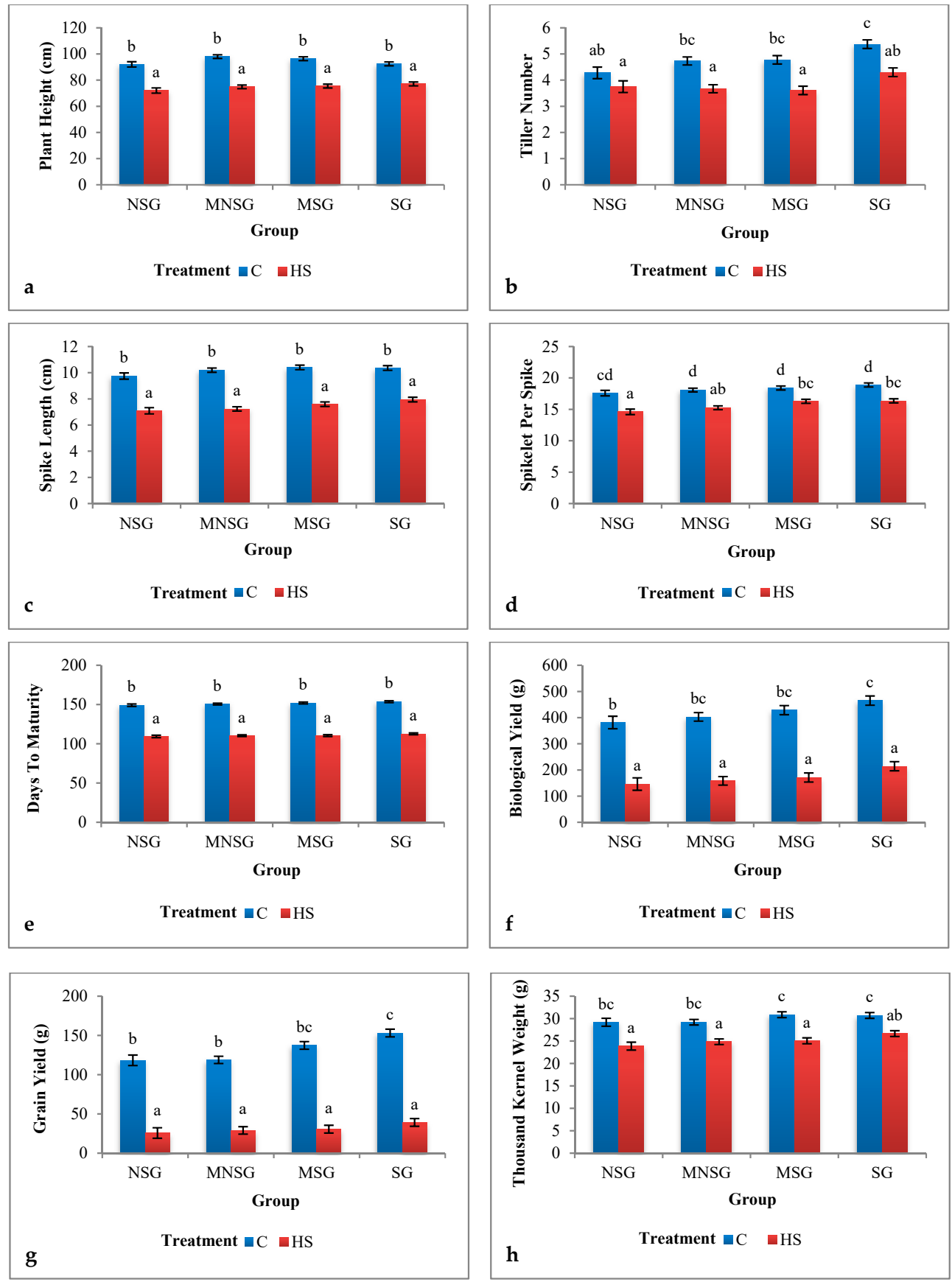

Figure 5. Variation in the morphological traits between the non-stay-green (NSG), moderately non-stay-green (MNSG), moderately stay-green (MSG), and stay-green (SG) groups under control (C) and heat stress (HS) conditions. (a) Plant height; (b) tiller number; (c) spike length; (d) spikelet per spike; (e) days to maturity; (f) biological yield; (g) grain yield; and (h) thousand kernel weight. Bars represent the least square means from the 2014-2015 and 2015-2016 field experiments. Error bars depict the standard errors and different lowercase letters representing significant differences among the groups and treatments at $p<0.05$. 


\subsubsection{Greenhouse Experiment}

\section{Physiological Traits}

The chlorophyll content decreased in the non-stay-green genotype after seven days from anthesis and the value declined with an increase in duration under high temperature stress. In the non-stay-green genotype, the decline in chlorophyll content was $25 \%$ and $85 \%$ after seven and fourteen days from anthesis, respectively, whereas the functional and non-functional stay-green genotypes maintained the chlorophyll content during high temperature stress (Figure 6a, Table S5).
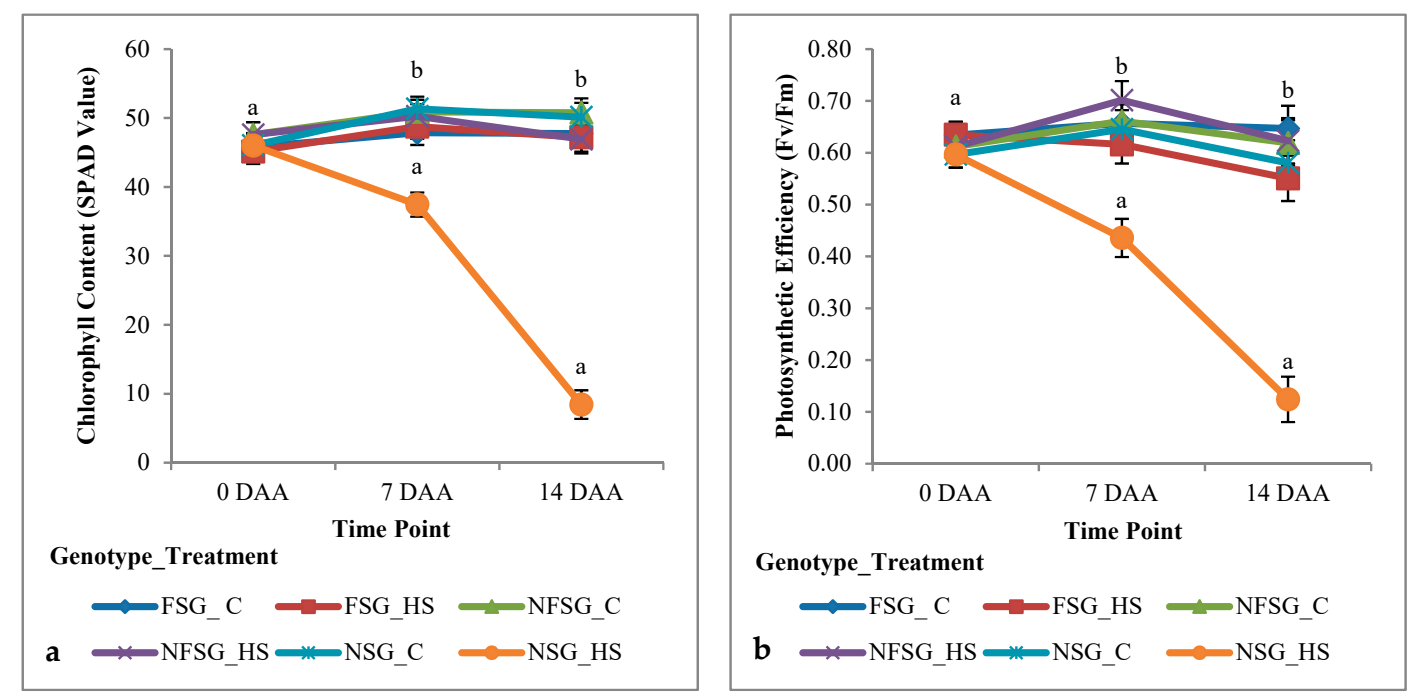

Figure 6. Chlorophyll content and photosynthetic efficiency in the functional stay-green (FSG), non-functional stay-green (NFSG), and non-stay-green (NSG) genotypes at 0, 7, and 14 days after anthesis under control (C) and high temperature stress (HS). (a) Chlorophyll content; and (b) photosynthetic efficiency. Line graphs represent the least square means. Error bars represent standard errors and different lowercase letters indicate the significant differences among genotypes and treatments at $p<0.05$.

The ØII decreased in the non-stay-green and functional stay-green genotypes under heat stress treatment compared to the control. The percentage decrease observed in the non-stay-green genotype was $32 \%$ and $79 \%$ after seven and fourteen days from anthesis under high temperature stress. Whereas the functional stay-green genotype showed $6 \%$ and $15 \%$ decline in the ØII compared to the control after seven and fourteen days of heat stress (Figure 6b, Table S5).

\section{Biological Yield and Grain Yield}

The BY varied greatly among functional stay-green, non-functional stay-green, and non-stay-green genotypes. The BY significantly declined under terminal heat stress conditions in the non-stay-green genotype. The functional stay-green genotype showed a maximum yield under the control and stress conditions. The functional stay-green, non-functional stay-green, and non-stay-green genotypes showed $6.7 \%, 7 \%$, and 52\% decline in the biomass, compared to the control (Figure 7a, Table S5). 

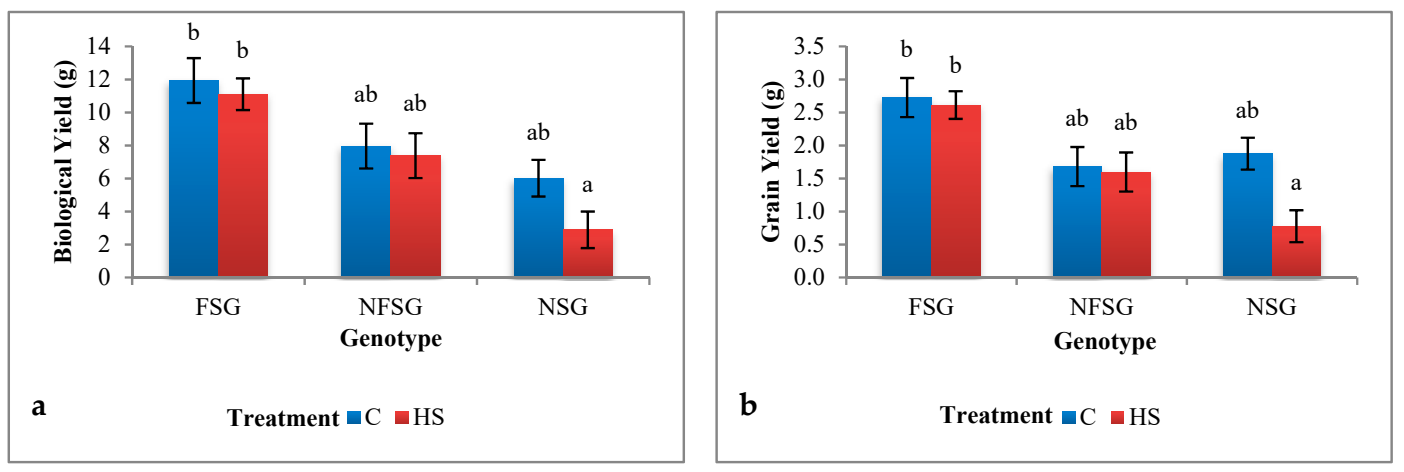

Figure 7. Biological yield and grain yield of the functional stay-green (FSG), non-functional stay-green (NFSG), and non-stay-green genotypes (NSG) under control (C) and terminal heat stress (HS) conditions. (a) Biological yield; and (b) grain yield. Bars represent the least square means and the error bars refer to the standard errors. Different lowercase letters represent significant difference among the genotypes and treatments at $p<0.05$.

The GY varied significantly among all the genotypes. The functional stay-green genotype showed a maximum yield under the control and stress conditions. The percentage reduction in the GY was $4 \%$, $5 \%$, and $59 \%$ in the functional stay-green, non-functional stay-green, and non-stay-green genotypes, respectively, under high temperature stress (Figure 7b, Table S5).

\subsection{Genotyping}

\subsubsection{Identification of $\mathrm{CaO}, \mathrm{Cab}, \mathrm{SGR}$, and RCCR in the Wheat Genome}

The $\mathrm{CaO}, \mathrm{Cab}, \mathrm{SGR}$, and RCCR in Triticum aestivum consisted of nine exons of $1653 \mathrm{bp}$, a single exon of $800 \mathrm{bp}$, three exons of $843 \mathrm{bp}$, and two exons of $1002 \mathrm{bp}$, respectively, as coding regions. The coding regions and protein sequences of $\mathrm{CaO}, \mathrm{Cab}, \mathrm{SGR}$, and RCCR in Triticum aestivum, Brachypodium distachyon, Hordeum vulgare, Oryza sativa, Sorghum bicolor, and Zea mays showed a high degree of homology (Table 1).

\subsubsection{Phylogenetics of $\mathrm{CaO}, \mathrm{Cab}, \mathrm{SGR}$, and RCCR}

Phylogenetic analysis was performed using the amino acid sequences for the targeted genes from Triticum aestivum, Brachypodium distachyon, Hordeum vulgare, Sorghum bicolor, Oryza sative, and Zea mays. Phylogenetic analysis revealed a close relationship of Triticum aestivum and Hordeum vulgare for the $\mathrm{CaO}, \mathrm{Cab}$, and SGR, whereas the maximum similarity was observed between Triticum aestivum and Oryza sative for the RCCR gene (Figure 8). 
Table 1. Homology in the coding regions and amino acid sequences of chlorophyllide a oxygenase (CaO), light-harvesting complex (Cab), stay-green (SGR), and red chlorophyll catabolite reductase (RCCR) in Triticum aestium, Brachypodium distachyon, Hordeum vulgare, Oryza sativa, Sorghum bicolor, and Zea mays.

\begin{tabular}{|c|c|c|c|c|c|c|c|c|c|c|c|c|c|}
\hline \multirow{2}{*}{ Gene } & \multirow{2}{*}{ Plant } & \multicolumn{2}{|c|}{ Triticum aestivum } & \multicolumn{2}{|c|}{ Brachypodium distachyon } & \multicolumn{2}{|c|}{ Hordeum vulgare } & \multicolumn{2}{|c|}{ Oryza sativa } & \multicolumn{2}{|c|}{ Sorghum bicolor } & \multicolumn{2}{|c|}{ Zea mays } \\
\hline & & $c D N A$ & Protein & cDNA & Protein & cDNA & Protein & $c D N A$ & Protein & $c D N A$ & Protein & cDNA & Protein \\
\hline \multirow{6}{*}{$\mathrm{CaO}$} & Triticum aestivum & 100 & 100 & 89.53 & 94.73 & 96.98 & 99.45 & 82.24 & 86.85 & 81.67 & 85.4 & 81.3 & 85.03 \\
\hline & Brachypodium distachyon & 89.53 & 94.73 & 100 & 100 & 89.66 & 94.55 & 84.65 & 88.15 & 82.35 & 87.06 & 81.92 & 86.32 \\
\hline & Hordeum vulgare & 96.98 & 99.45 & 89.66 & 94.55 & 100 & 100 & 82.31 & 87.04 & 81.55 & 85.58 & 81.06 & 85.21 \\
\hline & Oryza sativa & 82.24 & 86.85 & 84.65 & 88.15 & 82.31 & 87.04 & 100 & 100 & 84.98 & 90.74 & 84.31 & 90.74 \\
\hline & Sorghum bicolor & 81.67 & 85.4 & 82.35 & 87.06 & 81.55 & 85.58 & 84.98 & 90.74 & 100 & 100 & 93.49 & 95.57 \\
\hline & Zea mays & 81.3 & 85.03 & 81.92 & 86.32 & 81.06 & 85.21 & 84.31 & 90.74 & 93.49 & 95.57 & 100 & 100 \\
\hline \multirow{6}{*}{$\mathrm{Cab}$} & Triticum aestivum & 100 & 100 & 92.04 & 95.82 & 94.88 & 98.87 & 90.18 & 90.15 & 91.81 & 91.29 & 90.93 & 91.67 \\
\hline & Brachypodium distachyon & 92.04 & 95.82 & 100 & 100 & 91.16 & 96.2 & 86.51 & 91.19 & 88.04 & 91.95 & 87.28 & 91.95 \\
\hline & Hordeum vulgare & 94.88 & 98.87 & 91.16 & 96.2 & 100 & 100 & 87.3 & 90.53 & 89.56 & 91.67 & 87.92 & 92.05 \\
\hline & Oryza sativa & 90.18 & 90.15 & 86.51 & 91.19 & 87.3 & 90.53 & 100 & 100 & 90.15 & 92.83 & 89.14 & 92.08 \\
\hline & Sorghum bicolor & 91.81 & 91.29 & 88.04 & 91.95 & 89.56 & 91.67 & 90.15 & 92.83 & 100 & 100 & 95.61 & 98.49 \\
\hline & Zea mays & 90.93 & 91.67 & 87.28 & 91.95 & 87.92 & 92.05 & 89.14 & 92.08 & 95.61 & 98.49 & 100 & 100 \\
\hline \multirow{6}{*}{ SGR } & Triticum aestivum & 100 & 100 & 82.21 & 76.43 & 94.55 & 93.07 & 80.54 & 77.69 & 77.96 & 74.62 & 79.49 & 73.83 \\
\hline & Brachypodium distachyon & 82.21 & 76.43 & 100 & 100 & 83.21 & 77.42 & 80.58 & 77.82 & 76 & 75 & 77.72 & 76.52 \\
\hline & Hordeum vulgare & 94.55 & 93.07 & 83.21 & 77.42 & 100 & 100 & 81.68 & 77.01 & 78.47 & 73.31 & 79.1 & 72.41 \\
\hline & Oryza sativa & 80.54 & 77.69 & 80.58 & 77.82 & 81.68 & 77.01 & 100 & 100 & 80.1 & 77.44 & 78.97 & 75.29 \\
\hline & Sorghum bicolor & 77.96 & 74.62 & 76 & 75 & 78.47 & 73.31 & 80.1 & 77.44 & 100 & 100 & 87.61 & 82.97 \\
\hline & Zea mays & 79.49 & 73.83 & 77.72 & 76.52 & 79.1 & 72.41 & 78.97 & 75.29 & 87.61 & 82.97 & 100 & 100 \\
\hline \multirow{6}{*}{ RCCR } & Triticum aestivum & 100 & 100 & 79.61 & 73.93 & 91.75 & 92.68 & 79.9 & 79.92 & 73.29 & 69.6 & 72.71 & 67.38 \\
\hline & Brachypodium distachyon & 79.61 & 73.93 & 100 & 100 & 80.23 & 77.83 & 78.3 & 76.19 & 74.64 & 69.44 & 73.31 & 68.83 \\
\hline & Hordeum vulgare & 91.75 & 92.68 & 80.23 & 77.83 & 100 & 100 & 79.45 & 79.51 & 75.73 & 73.17 & 74.92 & 73.66 \\
\hline & Oryza sativa & 79.9 & 79.92 & 78.3 & 76.19 & 79.45 & 79.51 & 100 & 100 & 74.32 & 74.41 & 73.67 & 73.23 \\
\hline & Sorghum bicolor & 73.29 & 69.6 & 74.64 & 69.44 & 75.73 & 73.17 & 74.32 & 74.41 & 100 & 100 & 90.59 & 90.66 \\
\hline & Zea mays & 72.71 & 67.38 & 73.31 & 68.83 & 74.92 & 73.66 & 73.67 & 73.23 & 90.59 & 90.66 & 100 & 100 \\
\hline
\end{tabular}




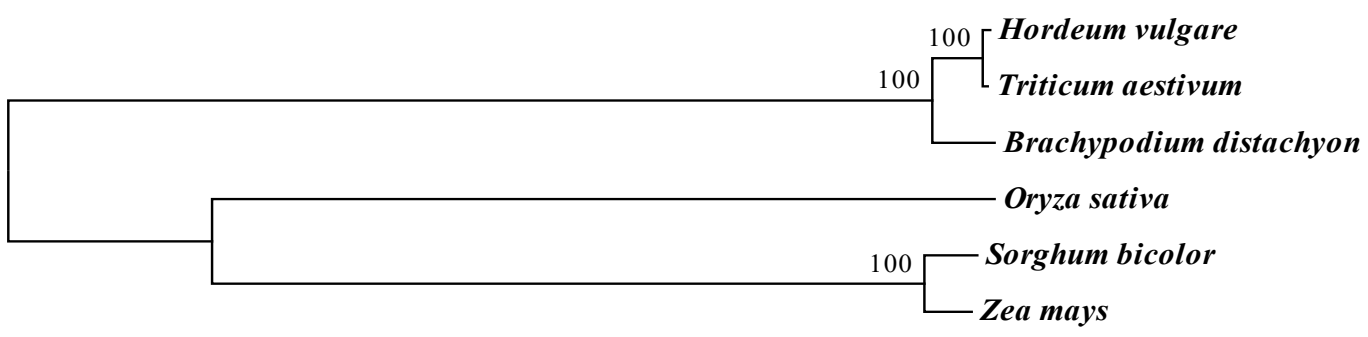

a
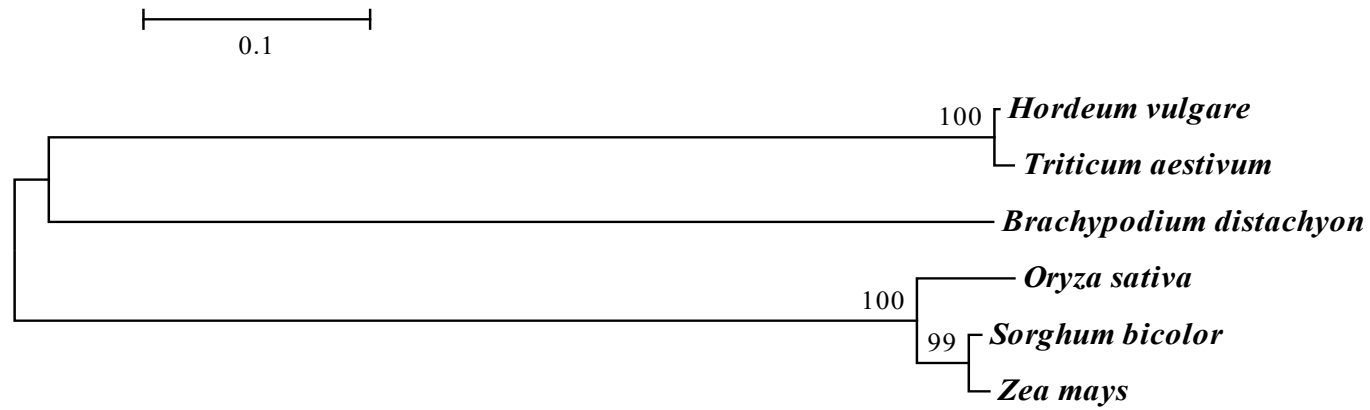

b
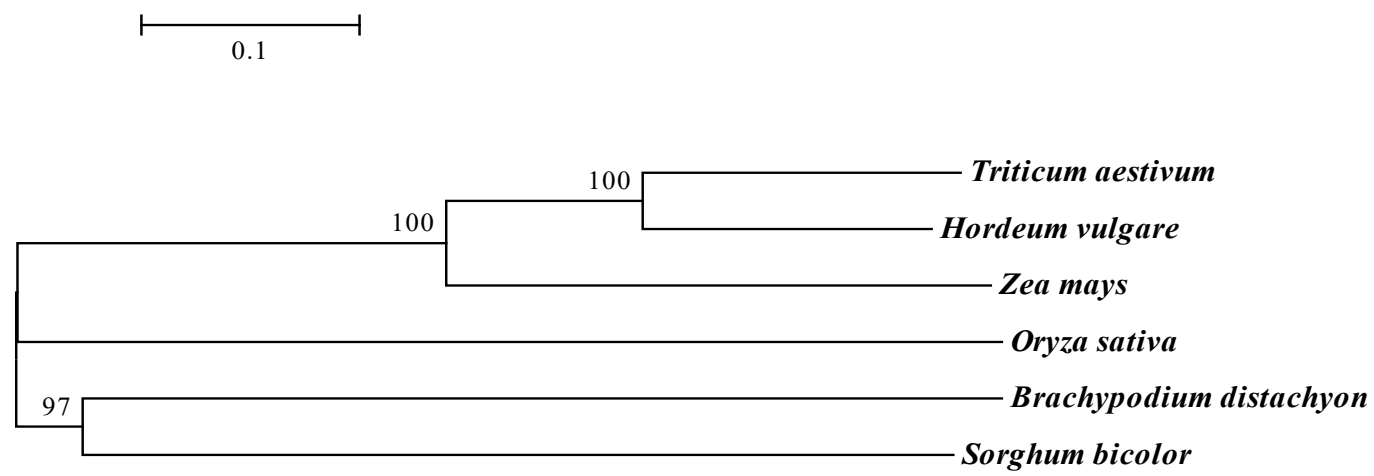

C
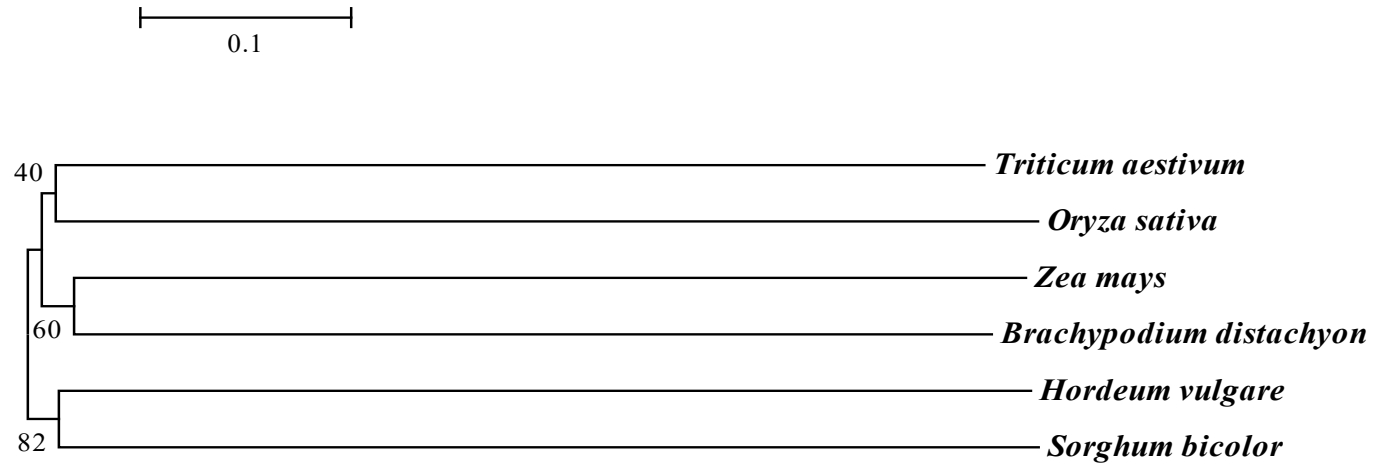

d

0.1

Figure 8. Phylogenetic analysis of the $\mathrm{CaO}, \mathrm{Cab}, \mathrm{SGR}$, and RCCR using protein sequences from Triticum aestivum, Brachypodium distachyon, Hordeum vulgare, Sorghum bicolor, Oryza sative, and Zea mays. (a) CaO; (b) Cab; (c) SGR; (d) RCCR.

\subsubsection{Amplification and Sequencing of $\mathrm{CaO}, \mathrm{Cab}$, SGR, and RCCR}

The $\mathrm{CaO}, \mathrm{Cab}, \mathrm{SGR}$, and RCCR genes were amplified in functional stay-green, non-functional stay-green, and non-stay-green genotypes. The amplified regions were sequenced to explore the variations in the gene sequences among functional stay-green, non-functional stay-green, and non-stay-green genotypes (Tables S1 and S6). 
The partial sequences of Cab and SGR genes showed no variation between functional stay-green, non-functional stay-green, and non-stay-green genotypes. The $\mathrm{CaO}$ gene revealed a single nucleotide variation in the non-stay-green genotype where cytosine was replaced by guanine at the position 292 of exon 8 . This resulted in a change in amino acid sequence at the position 489 where glutamic acid was replaced by aspartic acid in the non-stay-green genotype. The partial RCCR gene sequence revealed great variation. The amino acid sequence of RCCR showed variations at position 204 (valine is replaced by alanine), 264 (alanine is replaced by glycine), 275 (valine is replaced by glycine), and 290 (lysine is replaced by arginine) in the functional stay-green and non-stay-green genotypes.

\subsubsection{Expression Analysis of $\mathrm{CaO}, \mathrm{Cab}$, SGR, and RCCR under Terminal Heat Stress}

Expression profiling in relation to the stay-green trait was performed using functional stay-green, non-functional stay-green, and non-stay-green genotypes. Expression profiling was done at anthesis, 7DAA, and 14DAA in the control and heat-treated samples with three biological replicates and three technical replicates. The amplification efficiency for the Actin2, CaO, Cab, SGR, and RCCR genes primers were found between 91 and $103.9 \%$.

The expression pattern of the $\mathrm{CaO}$ gene revealed a significant relation with the stay-green trait. In the functional stay green genotype, an up-regulation of the $\mathrm{CaO}$ gene was observed at 7DAA. However, the relative abundance of the gene transcript was reduced till 14DAA. In the non-functional stay-green genotype, the gene transcript slightly increased at 14DAA. The non-stay-green genotype showed a significant decrease in the $\log 2$ fold change of the $\mathrm{CaO}$ gene at 7DAA under terminal heat stress condition (Figure 9a).

The expression pattern of the Cab gene also showed significant relation with the stay-green trait. The $\log 2$ fold change of the Cab gene revealed a decrease in the relative abundance of the gene transcript among all the genotypes. However, the decrease was more pronounced in the non-stay-green genotype at 7DAA (Figure 9b).

The expression analysis of the SGR gene revealed an increase in the gene transcript among all the genotypes under heat stress treatment. There was a constant increase in the SGR gene transcript in the functional stay-green and non-stay-green genotypes, whereas an increase in the expression of the SGR gene in non-functional stay green was more obvious after 7 days of anthesis (Figure 9c).

Expression analysis depicted an up-regulation of the RCCR gene in functional stay-green, non-functional stay-green, and non-stay-green genotypes. The relative abundance of the gene transcript increased consistently after day 7 and 14 of anthesis in the functional stay-green genotype. In non-functional stay-green and non-stay-green genotypes, an increase in the expression of RCCR gene was more evident at 7DAA (Figure 9d). 

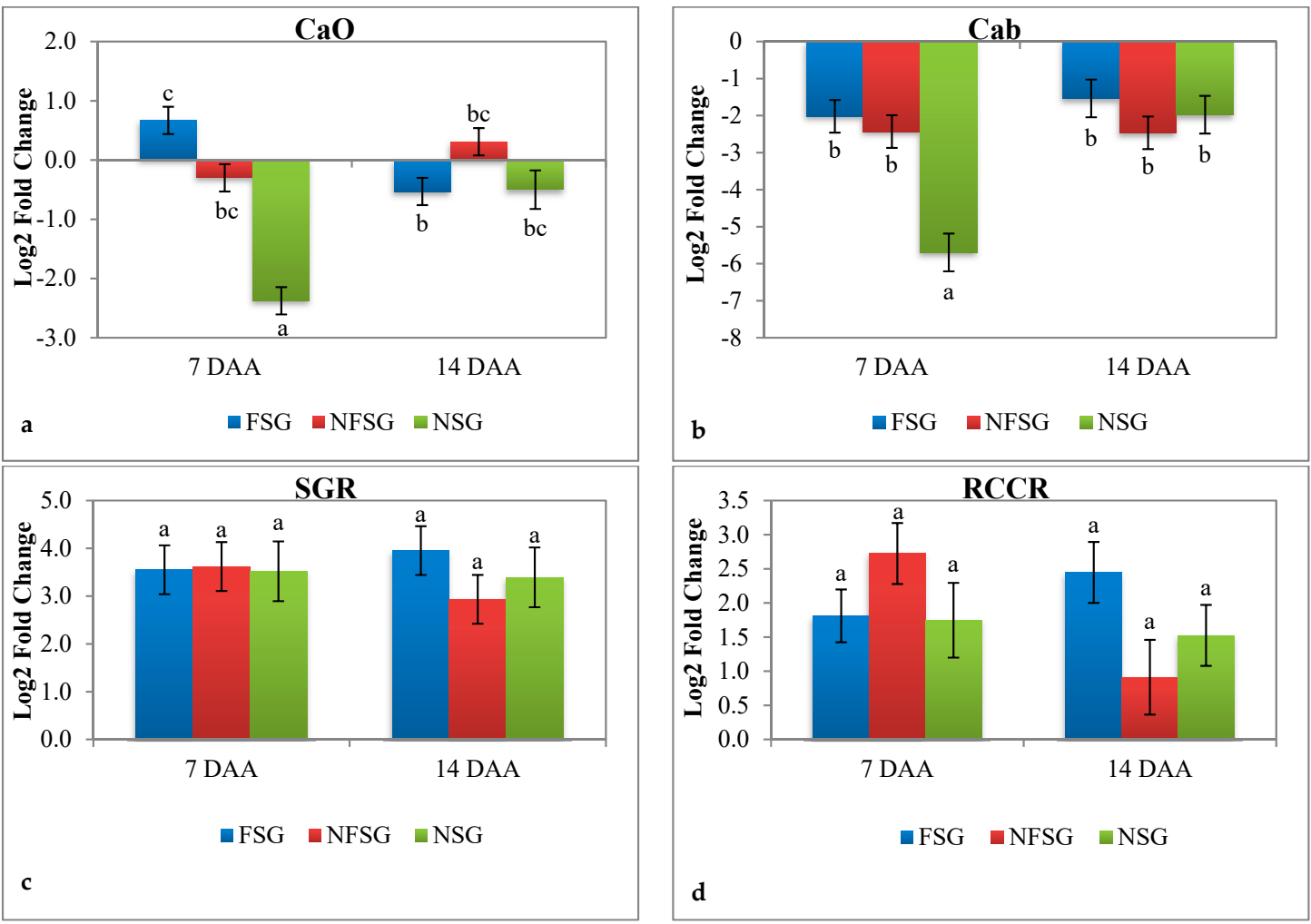

Figure 9. Fold change in the relative abundance of the $\mathrm{CaO}, \mathrm{Cab}, \mathrm{SGR}$, and RCCR gene transcripts among functional stay-green (FSG), non-functional stay-green (NFSG), and non-stay-green (NSG) genotypes under terminal heat stress. FSG: functional stay-green (Nepal-38), NFSG: non-functional stay-green (SG-30), and NSG: non-stay-green (Sonalika). (a) Expression pattern of CaO; (b) expression pattern of $\mathrm{Cab}$; (c) expression pattern of SGR; and (d) expression pattern of RCCR. Bar represents the least square mean of the $\log 2$ fold change using three biological and three technical replicates. The error bars refer to the standard errors and the different lowercase letters represent significant difference among the genotypes at $p<0.05$.

\section{Discussion}

Global temperature is predicted to increase by $3{ }^{\circ} \mathrm{C}$ to $5{ }^{\circ} \mathrm{C}$ by the end of the $21^{\text {st }}$ century [66]. The increasing global temperature is of major concern to sustainable agriculture. High temperature stress adversely affects plant productivity, particularly when it occurs during reproductive and grain filling period of the plant life cycle [7,67]. The stay-green trait has been considered as a mechanism of tolerance to terminal heat stress. Since crop productivity is related to the duration and rate of senescence, it is expected that stay-green genotypes with longer grain-filling duration and a faster grain filling rate can sustain productivity under stress [59]. Studies have reported the association of the stay-green trait with better performance in wheat under terminal heat stress $[18,59,60]$. In the present study, the germplasm consisting of land races, green revolution, post green revolution, elite genotypes, and synthetic derivatives was categorized into non-stay-green, moderately non-stay-green, moderately stay-green, and stay-green groups on the basis of the NDVI. The use of the Green-seeker to measure the NDVI is a high throughput approach that has been used for the precise quantification of the stay-green trait in recent years. It offers an integrated measure of the total canopy greenness including the leaves, stems, and spikes $[18,68,69]$. The Chlorophyll meter and visual scoring were also used to measure the stay-green trait $[70,71]$, but these approaches are more subjective. The current study demonstrated the response of the non-stay-green, moderately non-stay-green, moderately stay-green, and stay-green genotypes to terminal heat stress under field conditions. The PH, Til No, SL, SpS, chlorophyll content, NDVI, GY, BY, and the TKW significantly declined, whereas the CT increased under high temperature 
stress among all the groups, while several previous studies reported a reduction in chlorophyll content, the Til No, kernel weight, shoot, and grain mass under high temperature stress [72-74]. However, the genotypes depicting the stay-green trait showed a significantly high chlorophyll content, NDVI, GY, BY, TKW, and low CT under the control and terminal heat stress treatments. A study by Pinto and coworkers also revealed a positive association of the stay-green trait with the yield, TKW, and low $\mathrm{CT}$ in wheat under terminal heat stress [18]. The association of the stay-green trait with low canopy temperature confirms a link between the stay-green expression, roots, and gas exchange, whereas a high value of canopy temperature in non-stay-green genotypes is an indicator of low evaporative cooling that is linked with low stomatal conductance and gas exchange. Christopher et al. [75] proposed that stay-green genotypes can extract extra moisture late in the season which confers a yield advantage.

The greenhouse experiment was conducted to elucidate the stay-green trait in functional stay-green, non-functional stay-green, and non-stay-green genotypes under terminal heat stress. Chlorophyll content and photosynthetic efficiency significantly declined in the non-stay-green genotype after seven days from the anthesis, whereas the functional stay-green and non-functional stay-green genotypes showed negligible variations. Thomas and Ougham attributed the retention of greenness and photosynthetic efficiency in the functional stay-green genotypes to yield improvement [19]. In the present study, the maintenance of the chlorophyll content and photosynthetic efficiency resulted in increased BY and GY in the functional stay-green genotype under the control and heat stress treatments. Despite the increased chlorophyll content and photochemical efficiency in the non-functional stay-green genotype, the low BY and GY can be presumed to be due to the disruption in nutrient assimilation or yield improvement locus on the chromosome seven of wheat that was not linked with the stay-green phenotype [18]. Whereas the functional stay-green trait may be controlled by quantitative trait loci (QTLs) that are common for stay-green, yield, and yield components [18]. The present study also confirmed that the reduction in photosynthetic efficiency was proportional to the yield reduction in the functional stay-green, non-functional stay-green, and non-stay-green genotypes under terminal heat stress.

The genetic basis behind the stay-green trait is complex and varies in different plant species. The multi-protein complex that includes chlorophyll catabolic enzymes, stay-green protein, and the light-harvesting complex protein is considered to be associated with the stay-green trait [29]. In the present study, selected chlorophyll catabolism and photosynthetic responsive genes were analyzed. The cDNA and protein sequences of $\mathrm{CaO}, \mathrm{Cab}$, SGR, and RCCR obtained from Triticum aestivum, Brachypodium distachyon, Hordeum vulgare, Oryza sativa, Sorghum bicolor, and Zea mays showed a high degree of percentage similarity. A previous study by Mueller and coworkers showed great percentage similarity in the amino acid sequences of $\mathrm{CaO}$ in Hordeum vulgare, Arabidopsis thaliana, Brachypodium distachyon, and Oryza sativa (OsCaO 1, OsCaO2) [76]. Xiao and coworkers showed high sequence homology between the RCCR gene sequences from Solanum lycopersicum, Nicotiana tabacum, Vitis vinifera, Ricinus communis, Fragaria vesca subsp vesca, Brassica napus, and Arabidopsis thaliana [77]. High sequence homology suggests that the genes are highly conserved during evolution [78]. The present study also revealed the partial gene sequences and amino acid sequences of $\mathrm{CaO}, \mathrm{Cab}$, SGR, and RCCR in functional stay-green, non-functional stay-green, and non-stay-green genotypes. The $\mathrm{CaO}$ and RCCR sequences showed few variations. These sequence variations need to be explored in the complete germplasm to be used as potential biomarkers for the marker-assisted selection for the stay-green trait in wheat. The expression pattern of $\mathrm{CaO}, \mathrm{Cab}, \mathrm{SGR}$, and RCCR at ODAA, 7DAA and 14DAA was determined in functional stay-green, non-functional stay-green, and non-stay-green genotypes. The expression profiling of the $\mathrm{CaO}$ gene showed significant relation with the stay-green trait. The $\mathrm{CaO}$ gene was up-regulated in the functional stay-green genotype and down-regulated in the non-stay-green genotype at 7DAA. It is assumed that the increased abundance of the CaO gene transcript in the stay-green genotype was associated with delayed senescence. Sakuraba et al. [29] and Kusaba et al. [79] previously reported that an over expression of the $\mathrm{CaO}$ gene transcript can cause increased chlorophyll $\mathrm{b}$ accumulation and delayed senescence $[29,79]$. The over expression of the $\mathrm{CaO}$ 
gene in Arabidopsis resulted in reduced chlorophyll a:b ratio and an increased light-harvesting complex apoprotein [80]. Biswal et al. [45] reported the controlled up-regulation of the $\mathrm{CaO}$ gene that resulted in increased chlorophyll $\mathrm{b}$ biosynthesis and modulated the expression of several thylakoid proteins, which increased the antenna size, rate of electron transport, carbon dioxide assimilation, and dry matter accumulation. The $\mathrm{CaO}$ mutant pale green leaf (pgl) in rice with chlorophyll b deficiency exhibited early senescence under terminal heat stress due to the accumulation of reactive oxygen species [81]. Expression profiling of photosynthetic responsive Cab gene depicted a reduction in gene transcript among all the genotypes under terminal heat stress. However, the decline in the expression of the Cab gene in the non-stay-green genotype was far greater compared to the functional stay-green and non-functional stay-green genotypes at 7DAA. The expression pattern of the Cab gene intriguingly correlates to the stay-green trait. The down-regulation of the LHCP genes under biotic and abiotic stresses has been reported in several studies [46-49,82]. The up-regulation of the Cab gene is associated with increased photosynthetic capacity [83]. In the present study, the expression analysis of SGR showed non-significant variation between the genotypes. However, the up-regulation of the SGR gene was observed among all the genotypes under terminal heat stress. The expression profiling before day seven of heat stress may illustrate the role of the SGR gene in functional stay-green, non-functional stay-green, and non-stay-green genotypes. Park et al. [78] revealed an increase in chlorophyll degradation with the increase in SGR expression. Moreover, it has been reported previously that the number of SGR genes varies among species and homologous SGR genes are not always associated with yellowing. In Arabidopsis, SGR1 over expression promoted leaf yellowing, whereas SGR2 over expression caused the stay-green phenotype [84]. The current study revealed an up-regulation of the RCCR gene among all the genotypes under heat stress, whereas no significant variation was observed between the genotypes. The increase in the relative abundance of the gene transcript was more pronounced in the non-functional stay-green type at 7DAA and in the functional stay-green genotype at 14DAA. CaRCCR gene up-regulation under biotic and abiotic stresses had been previously reported by Xiao et al. [77]. The up-regulation of the RCCR gene is associated with the defense responses in plants under stress conditions [77]. The present study demonstrated that the expression pattern of $\mathrm{CaO}$ and $\mathrm{Cab}$ at 7DAA is proportional to the increase/decrease in the chlorophyll content and photosynthetic capacity in functional stay-green, non-functional stay-green, and non-stay-green genotypes under terminal heat stress.

\section{Conclusions}

The present study suggested an integrated way to classify a large set of genotypes into non-stay-green, moderately non-stay-green, moderately stay-green, and stay-green types on the basis of the NDVI values recorded between heading and maturity. All the morpho-physiological traits showed significant variations among non-stay-green, moderately non-stay-green, moderately stay-green, and stay-green types under control and heat stress treatments. The genotypes characterized into the stay-green type depicted a high chlorophyll content, NDVI, GY, BY, and TKW, and a low CT under control and heat stress conditions. The study also revealed the response of functional stay-green, non-functional stay-green, and non-stay-green genotypes to terminal heat stress. Chlorophyll content and photochemical efficiency was retained for a longer duration under control and heat stress treatments in both the functional stay-green and non-functional stay-green, however the non-functional stay-green genotype showed shriveled grains. Thus, unraveling a non-functional stay-green type in which the chlorophyll content and photosynthetic efficiency was maintained but nutrient assimilation was considered to be disrupted. The percentage reduction in biological yield and grain yield under stress corresponded to the decline in chlorophyll content and photosynthetic efficiency. The partial gene sequences of $\mathrm{CaO}$ and RCCR; and the expression profiling of $\mathrm{CaO}$ and $\mathrm{Cab}$ revealed significant variations between functional stay-green, non-functional stay-green, and non-stay-green genotypes. Collectively, the results indicate that the stay-green phenotype can significantly mitigate the harmful aspects of terminal heat stress by sustaining grain yield and biological yield. Moreover, the stay-green 
trait is a complex trait that needs to be explored at greater depth using high throughput phenomics and functional genomics tools.

Supplementary Materials: The following are available online at http:/www.mdpi.com/2073-4395/10/7/1001/s1, Table S1: List of genotypes, pedigree, and grouping of germplasm used in the study, Table S2: Coding Sequence ID and Protein ID of CaO, Cab, SGR, and RCCR in Brachypodium distachyon, Hordeum vulgare, Sorghum bicolor, Oryza sativa, Zea mays, and Gene ID of Triticum aestivum, Table S3: List of oligonucleotide primer sequences used for the amplification and expression analysis of the $\mathrm{CaO}, \mathrm{Cab}$, SGR, and RCCR in Triticum aestivum, Table S4: Basic statistics for the phenotypic traits measured in stay-green, moderately stay-green, moderately non-stay-green, and non-stay-green groups under control and heat stress treatments in the field experiments, Table S5: Basic statistics for the phenotypic traits measured in functional stay-green, non-functional stay-green, and non-stay-green genotypes under control and heat stress treatments in the greenhouse experiment, Table S6: Gene bank accession number for the $\mathrm{CaO}, \mathrm{Cab}, \mathrm{SGR}$, and RCCR genes, S1: Multiple sequence alignment of $\mathrm{CaO}, \mathrm{Cab}$, SGR, and RCCR.

Author Contributions: Conceptualization, S.L., M.A.B., J.W., and U.M.Q.; methodology, S.L., L.W., J.W., and U.M.Q.; software, S.L. and J.K.; validation, S.L. and Z.A.; formal analysis, S.L. and J.K.; investigation, S.L.; resources, S.K.S., M.A.B., J.W., and U.M.Q.; data curation, S.L.; writing-original draft preparation, S.L.; writing-review and editing, Z.A. and U.M.Q.; visualization, S.L. and Z.A.; supervision, U.M.Q. All authors have read and agreed to the published version of the manuscript.

Funding: This research was funded by Higher Education Commission, Pakistan and Department of Agronomy, University of Florida.

Acknowledgments: We deeply acknowledge Wheat Wide Crosses and Cytogenetics Laboratory, National Agricultural Research Centre, Islamabad for providing field facilities for experimentation. We acknowledge South Dakota State University for providing greenhouse facility. We also acknowledge Navjot Kaur, fellow researcher at South Dakota State University for her assistance.

Conflicts of Interest: The authors declare no conflict of interest.

\section{References}

1. Arunanondchai, P.; Fei, C.; Fisher, A.; McCarl, B.A.; Wang, W.; Yang, Y. How does climate change affect agriculture. In The Routledge Handbook of Agricultural Economics, 1st ed.; Cramer, G.L., Paudel, K.P., Schmitz, A., Eds.; Routledge: Abingdon-on-Thames, UK, 2018; pp. 191-210.

2. Noya, I.; González-García, S.; Bacenetti, J.; Fiala, M.; Moreira, M.T. Environmental impacts of the cultivation-phase associated with agricultural crops for feed production. J. Clean. Prod. 2018, 172, 3721-3733. [CrossRef]

3. Raza, A.; Razzaq, A.; Mehmood, S.S.; Zou, X.; Zhang, X.; Lv, Y.; Xu, J. Impact of climate change on crops adaptation and strategies to tackle its outcome: A review. Plants 2019, 8, 34. [CrossRef] [PubMed]

4. Fontana, G.; Toreti, A.; Ceglar, A.; De Sanctis, G. Early heat waves over Italy and their impacts on durum wheat yields. Nat. Hazard. Earth Syst. 2015, 15, 1631-1637. [CrossRef]

5. Mueller, B.; Hauser, M.; Iles, C.; Rimi, R.H.; Zwiers, F.W.; Wan, H. Lengthening of the growing season in wheat and maize producing regions. Weather Clim. Extrem. 2015, 9, 47-56. [CrossRef]

6. Hays, D.; Mason, E.; Do, J.H.; Menz, M.; Reynolds, M. Expression Quantitative Trait Loci Mapping Heat Tolerance During Reproductive Development in Wheat (Triticum Aestivum). In Wheat Production in Stressed Environments, Proceedings of the 7th International Wheat Conference, Mar del Plata, Argentina, 27 November-2 December 2005; Buck, H.T., Nisi, J.E., Salomon, N., Eds.; Springer: Dordrecht, The Netherlands, 2007; pp. 373-382.

7. Wollenweber, B.; Porter, J.; Schellberg, J. Lack of Interaction between Extreme High-Temperature Events at Vegetative and Reproductive Growth Stages in Wheat. J. Agron. Crop Sci. 2003, 189, 142-150. [CrossRef]

8. Siebert, S.; Ewert, F.; Eyshi Rezaei, E.; Kage, H.; Graß, R. Impact of heat stress on crop yield-On the importance of considering canopy temperature. Environ. Res. Lett. 2014, 9, 044012. [CrossRef]

9. Sharma, I.; Tyagi, B.; Singh, G.; Venkatesh, K.; Gupta, O. Enhancing wheat production-A global perspective. Indian J. Agric. Sci. 2015, 85, 3-13.

10. Akter, N.; Islam, M.R. Heat stress effects and management in wheat. A review. Agron. Sustain. Dev. 2017, 37, 37. [CrossRef]

11. Challinor, A.J.; Watson, J.; Lobell, D.B.; Howden, S.; Smith, D.; Chhetri, N. A meta-analysis of crop yield under climate change and adaptation. Nat. Clim. Chang. 2014, 4, 287-291. [CrossRef] 
12. Sairam, R.K.; Srivastava, G.C.; Saxena, D.C. Increased Antioxidant Activity under Elevated Temperatures: A Mechanism of Heat Stress Tolerance in Wheat Genotypes. Biol. Plant. 2000, 43, 245-251. [CrossRef]

13. Dias, A.; Lidon, F. Evaluation of grain filling rate and duration in bread and durum wheat, under heat stress after anthesis. J. Agron. Crop Sci. 2009, 195, 137-147. [CrossRef]

14. Wilkinson, S.; Davies, W.J. ABA-based chemical signalling: The co-ordination of responses to stress in plants. Plant Cell Environ. 2002, 25, 195-210. [CrossRef] [PubMed]

15. Balla, K.; Karsai, I.; Bencze, S.; Veisz, O. Germination ability and seedling vigour in the progeny of heat-stressed wheat plants. Acta Agron. Hung. 2012, 60, 299-308. [CrossRef]

16. Sharma, D.; Singh, R.; Tiwari, R.; Kumar, R.; Gupta, V.K. Wheat Responses and Tolerance to Terminal Heat Stress: A Review. In Wheat Production in Changing Environments; Hasanuzzaman, M., Nahar, K., Hossain, M., Eds.; Springer: Singapore, 2019; pp. 149-173. [CrossRef]

17. Kumari, M.; Singh, V.P.; Tripathi, R.; Joshi, A.K. Variation for Staygreen Trait and its Association with Canopy Temperature Depression and Yield Traits Under Terminal Heat Stress in Wheat. In Wheat Production in Stressed Environments. Developments in Plant Breeding; Buck, H.T., Nisi, J.E., Salomón, N., Eds.; Springer: Dordrecht, The Netherlands, 2007; Volume 12, pp. 357-363. [CrossRef]

18. Pinto, R.S.; Lopes, M.S.; Collins, N.C.; Reynolds, M.P. Modelling and genetic dissection of staygreen under heat stress. Theor. Appl. Genet. 2016, 129, 2055-2074. [CrossRef] [PubMed]

19. Thomas, H.; Ougham, H. The stay-green trait. J. Exp. Bot. 2014, 65, 3889-3900. [CrossRef] [PubMed]

20. Hortensteiner, S. Stay-green regulates chlorophyll and chlorophyll-binding protein degradation during senescence. Trends Plant Sci. 2009, 14, 155-162. [CrossRef]

21. Armstead, I.; Donnison, I.; Aubry, S.; Harper, J.; Hörtensteiner, S.; James, C.; Mani, J.; Moffet, M.; Ougham, H.; Roberts, L. From crop to model to crop: Identifying the genetic basis of the staygreen mutation in the Lolium/Festuca forage and amenity grasses. New Phytol. 2006, 172, 592-597. [CrossRef]

22. Barry, C.S.; McQuinn, R.P.; Chung, M.Y.; Besuden, A.; Giovannoni, J.J. Amino acid substitutions in homologs of the STAY-GREEN protein are responsible for the green-flesh and chlorophyll retainer mutations of tomato and pepper. Plant Physiol. 2008, 147, 179-187. [CrossRef]

23. Cha, K.W.; Lee, Y.J.; Koh, H.J.; Lee, B.M.; Nam, Y.W.; Paek, N.C. Isolation, characterization, and mapping of the stay green mutant in rice. Theor. Appl. Genet. 2002, 104, 526-532. [CrossRef]

24. Duvick, D.; Smith, J.; Cooper, M. Long-term selection in a commercial hybrid maize breeding program. Plant Breed. Rev. 2004, 24, 109-152. [CrossRef]

25. Fang, C.; Li, C.; Li, W.; Wang, Z.; Zhou, Z.; Shen, Y.; Wu, M.; Wu, Y.; Li, G.; Kong, L.A.; et al. Concerted evolution of D1 and D2 to regulate chlorophyll degradation in soybean. Plant J. 2014, 77, 700-712. [CrossRef] [PubMed]

26. Grbić, V.; Bleecker, A.B. Ethylene regulates the timing of leaf senescence in Arabidopsis. Plant J. 1995, 8, 595-602. [CrossRef]

27. Rampino, P.; Spano, G.; Pataleo, S.; Mita, G.; Napier, J.A.; Di Fonzo, N.; Shewry, P.R.; Perrotta, C. Molecular analysis of a durum wheat 'stay green' mutant: Expression pattern of photosynthesis-related genes. J. Cereal Sci. 2006, 43, 160-168. [CrossRef]

28. Wei, Q.; Guo, Y.; Kuai, B. Isolation and characterization of a chlorophyll degradation regulatory gene from tall fescue. Plant Cell Rep. 2011, 30, 1201-1207. [CrossRef]

29. Sakuraba, Y.; Schelbert, S.; Park, S.Y.; Han, S.H.; Lee, B.D.; Andrès, C.B.; Kessler, F.; Hörtensteiner, S.; Paek, N.C. STAY-GREEN and chlorophyll catabolic enzymes interact at light-harvesting complex II for chlorophyll detoxification during leaf senescence in Arabidopsis. Plant Cell 2012, 24, 507-518. [CrossRef]

30. Takamiya, K.; Tsuchiya, T.; Ohta, H. Degradation pathway (s) of chlorophyll: What has gene cloning revealed? Trends Plant Sci. 2000, 5, 426-431. [CrossRef]

31. Christ, B.; Hörtensteiner, S. Mechanism and significance of chlorophyll breakdown. J. Plant Growth Regul. 2014, 33, 4-20. [CrossRef]

32. Shimoda, Y.; Ito, H.; Tanaka, A. Arabidopsis STAY-GREEN, Mendel's Green Cotyledon Gene, Encodes Magnesium-Dechelatase. Plant Cell 2016, 28, 2147-2160. [CrossRef]

33. Suzuki, Y.; Doi, M.; Shioi, Y. Two enzymatic reaction pathways in the formation of pyropheophorbide a. Photosynth. Res. 2002, 74, 225. [CrossRef] 
34. Hortensteiner, S.; Vicentini, F.; Matile, P. Chlorophyll breakdown in senescent cotyledons of rape, Brassica napus L.: Enzymatic cleavage of phaeophorbide a in vitro. New Phytol. 1995, 129, 237-246. [CrossRef]

35. Hortensteiner, S.; Krautler, B. Chlorophyll breakdown in higher plants. Biochim. Biophys. Acta 2011, 1807, 977-988. [CrossRef] [PubMed]

36. Kuai, B.; Chen, J.; Hörtensteiner, S. The biochemistry and molecular biology of chlorophyll breakdown. J. Exp. Bot. 2017, 69, 751-767. [CrossRef] [PubMed]

37. Bellafiore, S.; Barneche, F.; Peltier, G.; Rochaix, J.D. State transitions and light adaptation require chloroplast thylakoid protein kinase STN7. Nature 2005, 433, 892-895. [CrossRef] [PubMed]

38. Niyogi, K.K.; Li, X.P.; Rosenberg, V.; Jung, H.S. Is PsbS the site of non-photochemical quenching in photosynthesis? J. Exp. Bot. 2004, 56, 375-382. [CrossRef]

39. Paulsen, H.; Dockter, C.; Volkov, A.; Jeschke, G. Folding and pigment binding of light-harvesting chlorophyll a/b protein (LHCIIb). In The Chloroplast; Rebeiz, C.A., Benning, C., Bohnert, H.J., Daniell, H., Hoober, J.K., Lichtenthaler, H.K., Portis, A.R., Tripathy, B.C., Eds.; Springer: Dordrecht, The Netherlands, 2010; Volume 31, pp. 231-244. [CrossRef]

40. Szabó, I.; Bergantino, E.; Giacometti, G.M. Light and oxygenic photosynthesis: Energy dissipation as a protection mechanism against photo-oxidation. EMBO Rep. 2005, 6, 629-634. [CrossRef]

41. Espineda, C.E.; Linford, A.S.; Devine, D.; Brusslan, J.A. The AtCAO gene, encoding chlorophyll a oxygenase, is required for chlorophyll b synthesis in Arabidopsis thaliana. Proc. Natl. Acad. Sci. USA 1999, 96, 10507-10511. [CrossRef]

42. Nagata, N.; Satoh, S.; Tanaka, R.; Tanaka, A. Domain structures of chlorophyllide a oxygenase of green plants and Prochlorothrix hollandica in relation to catalytic functions. Planta 2004, 218, 1019-1025. [CrossRef]

43. Oster, U.; Tanaka, R.; Tanaka, A.; Rüdiger, W. Cloning and functional expression of the gene encoding the key enzyme for chlorophyll b biosynthesis (CAO) from Arabidopsis thaliana. Plant J. 2000, 21, 305-310. [CrossRef]

44. Tanaka, A.; Ito, H.; Tanaka, R.; Tanaka, N.K.; Yoshida, K.; Okada, K. Chlorophyll a oxygenase (CAO) is involved in chlorophyll b formation from chlorophyll a. Proc. Natl. Acad. Sci. USA 1998, 95, 12719-12723. [CrossRef]

45. Biswal, A.K.; Pattanayak, G.K.; Pandey, S.S.; Leelavathi, S.; Reddy, V.S.; Tripathy, B.C. Light intensity-dependent modulation of chlorophyll $\mathrm{b}$ biosynthesis and photosynthesis by overexpression of chlorophyllide a oxygenase in tobacco. Plant Physiol. 2012, 159, 433-449. [CrossRef]

46. Guo, P.; Baum, M.; Grando, S.; Ceccarelli, S.; Bai, G.; Li, R.; Von-Korff, M.; Varshney, R.K.; Graner, A.; Valkoun, J. Differentially expressed genes between drought-tolerant and drought-sensitive barley genotypes in response to drought stress during the reproductive stage. J. Exp. Bot. 2009, 60, 3531-3544. [CrossRef] [PubMed]

47. Hazen, S.P.; Pathan, M.S.; Sanchez, A.; Baxter, I.; Dunn, M.; Estes, B.; Chang, H.S.; Zhu, T.; Kreps, J.A.; Nguyen, H.T. Expression profiling of rice segregating for drought tolerance QTLs using a rice genome array. Funct. Integr. Genom. 2005, 5, 104-116. [CrossRef] [PubMed]

48. Manickavelu, A.; Kawaura, K.; Oishi, K.; Shin-I, T.; Kohara, Y.; Yahiaoui, N.; Keller, B.; Suzuki, A.; Yano, K.; Ogihara, Y. Comparative gene expression analysis of susceptible and resistant near-isogenic lines in common wheat infected by Puccinia triticina. DNA Res. 2010, 17, 211-222. [CrossRef] [PubMed]

49. Seki, M.; Narusaka, M.; Ishida, J.; Nanjo, T.; Fujita, M.; Oono, Y.; Kamiya, A.; Nakajima, M.; Enju, A.; Sakurai, T. Monitoring the expression profiles of 7000 Arabidopsis genes under drought, cold and high-salinity stresses using a full-length cDNA microarray. Plant J. 2002, 31, 279-292. [CrossRef] [PubMed]

50. Jiang, H.; Li, M.; Liang, N.; Yan, H.; Wei, Y.; Xu, X.; Liu, J.; Xu, Z.; Chen, F.; Wu, G. Molecular cloning and function analysis of the stay green gene in rice. Plant J. 2007, 52, 197-209. [CrossRef] [PubMed]

51. Hörtensteiner, S. Chlorophyll degradation during senescence. Annu. Rev. Plant Biol. 2006, 57, 55-77. [CrossRef]

52. Sugishima, M.; Kitamori, Y.; Noguchi, M.; Kohchi, T.; Fukuyama, K. Crystal structure of red chlorophyll catabolite reductase: Enlargement of the ferredoxin-dependent bilin reductase family. J. Mol. Biol. 2009, 389, 376-387. [CrossRef]

53. Mach, J.M.; Castillo, A.R.; Hoogstraten, R.; Greenberg, J.T. The Arabidopsis-accelerated cell death gene ACD2 encodes red chlorophyll catabolite reductase and suppresses the spread of disease symptoms. Proc. Natl. Acad. Sci. USA 2001, 98, 771-776. [CrossRef] 
54. Pruzinska, A.; Anders, I.; Aubry, S.; Schenk, N.; Tapernoux-Luthi, E.; Muller, T.; Krautler, B.; Hortensteiner, S. In vivo participation of red chlorophyll catabolite reductase in chlorophyll breakdown. Plant Cell 2007, 19, 369-387. [CrossRef]

55. Cheng, Y.; Dong, Y.; Yan, H.; Ge, W.; Shen, C.; Guan, J.; Liu, L.; Zhang, Y. Effects of 1-MCP on chlorophyll degradation pathway-associated genes expression and chloroplast ultrastructure during the peel yellowing of Chinese pear fruits in storage. Food Chem. 2012, 135, 415-422. [CrossRef]

56. Tang, Y.; Li, M.; Chen, Y.; Wu, P.; Wu, G.; Jiang, H. Knockdown of OsPAO and OsRCCR1 cause different plant death phenotypes in rice. J. Plant Physiol. 2011, 168, 1952-1959. [CrossRef] [PubMed]

57. Yao, N.; Greenberg, J.T. Arabidopsis ACCELERATED CELL DEATH2 modulates programmed cell death. Plant Cell 2006, 18, 397-411. [CrossRef] [PubMed]

58. Zhang, X.; Zhang, Z.; Li, J.; Wu, L.; Guo, J.; Ouyang, L.; Xia, Y.; Huang, X.; Pang, X. Correlation of leaf senescence and gene expression/activities of chlorophyll degradation enzymes in harvested Chinese flowering cabbage (Brassica rapa var. parachinensis). J. Plant Physiol. 2011, 168, 2081-2087. [CrossRef] [PubMed]

59. Kumari, M.; Pudake, R.; Singh, V.; Joshi, A.K. Association of staygreen trait with canopy temperature depression and yield traits under terminal heat stress in wheat (Triticum aestivum L.). Euphytica 2013, 190, 87-97. [CrossRef]

60. Reynolds, M.P.; Gutiérrez-Rodríguez, M.; Larqué-Saavedra, A. Photosynthesis of wheat in a warm, irrigated environment: I: Genetic diversity and crop productivity. Field Crops Res. 2000, 66, 37-50. [CrossRef]

61. Pask, A.; Pietragalla, J.; Mullan, D.; Reynolds, M. Physiological Breeding II: A Field Guide to Wheat Phenotyping; Cimmyt: Mexico City, Mexico, 2012.

62. Tamura, K.; Stecher, G.; Peterson, D.; Filipski, A.; Kumar, S. MEGA6: Molecular evolutionary genetics analysis version 6.0. Mol. Biol. Evol. 2013, 30, 2725-2729. [CrossRef]

63. Nei, M.; Kumar, S. Molecular Evolution and Phylogenetics; Oxford University Press: Oxford, UK, 2000.

64. Buchner, P.; Tausz, M.; Ford, R.; Leo, A.; Fitzgerald, G.J.; Hawkesford, M.J.; Tausz-Posch, S. Expression patterns of $\mathrm{C}$-and $\mathrm{N}$-metabolism related genes in wheat are changed during senescence under elevated $\mathrm{CO}_{2}$ in dry-land agriculture. Plant Sci. 2015, 236, 239-249. [CrossRef]

65. Livak, K.J.; Schmittgen, T.D. Analysis of relative gene expression data using real-time quantitative PCR and the 2- $\Delta \Delta C T$ method. Methods 2001, 25, 402-408. [CrossRef]

66. Miles, T.; Liffey, K. Global Temperatures on Track for 3-5 Degree Rise by 2100: UN; Reuters: Geneva, Switzerland, 2018. Available online: https://www.reuters.com/article/us-climate-change-un/global-temperatures-ontrack-for-3-5-degree-rise-by-2100-u-n-idUSKCN1NY186 (accessed on 29 November 2018).

67. Farooq, M.; Bramley, H.; Palta, J.A.; Siddique, K.H. Heat stress in wheat during reproductive and grain-filling phases. Crit. Rev. Plant Sci. 2011, 30, 491-507. [CrossRef]

68. Christopher, M.; Chenu, K.; Jennings, R.; Fletcher, S.; Butler, D.; Borrell, A.; Christopher, J. QTL for stay-green traits in wheat in well-watered and water-limited environments. Field Crops Res. 2018, 217, 32-44. [CrossRef]

69. Lopes, M.S.; Reynolds, M.P. Stay-green in spring wheat can be determined by spectral reflectance measurements (normalized difference vegetation index) independently from phenology. J. Exp. Bot. 2012, 63, 3789-3798. [CrossRef] [PubMed]

70. Harris, K.; Subudhi, P.; Borrell, A.; Jordan, D.; Rosenow, D.; Nguyen, H.; Klein, P.; Klein, R.; Mullet, J. Sorghum stay-green QTL individually reduce post-flowering drought-induced leaf senescence. J. Exp. Bot. 2006, 58, 327-338. [CrossRef] [PubMed]

71. Kumar, U.; Joshi, A.K.; Kumari, M.; Paliwal, R.; Kumar, S.; Röder, M.S. Identification of QTLs for stay green trait in wheat (Triticum aestivum L.) in the 'Chirya 3'×'Sonalika'population. Euphytica 2010, 174, 437-445. [CrossRef]

72. Mohammadi, V.; Qannadha, M.; Zali, A.; Yazdi-Samadi, B. Effect of post anthesis heat stress on head traits of wheat. Int. J. Agric. Biol. 2004, 6, 42-44.

73. Shah, N.H.; Paulsen, G.M. Injury to photosynthesis and productivity from interaction between high temperature and drought during maturation of wheat. Asian J. Plant Sci. 2005, 4, 67-74. [CrossRef]

74. Viswanathan, C.; Khanna-Chopra, R. Effect of heat stress on grain growth, starch synthesis and protein synthesis in grains of wheat (Triticum aestivum L.) varieties differing in grain weight stability. J. Agron. Crop Sci. 2001, 186, 1-7. [CrossRef] 
75. Christopher, J.T.; Manschadi, A.M.; Hammer, G.L.; Borrell, A.K. Stay-green wheat for Australia's changing, dry environment. In Proceedings of the 11th International Wheat Genetics Symposium, Brisbane, Australia, 24-29 August 2018; Volume 1, p. 119.

76. Mueller, A.H.; Dockter, C.; Gough, S.P.; Lundqvist, U.; von Wettstein, D.; Hansson, M. Characterization of mutations in barley fch2 encoding chlorophyllide a oxygenase. Plant Cell Physiol. 2012, 53, 1232-1246. [CrossRef]

77. Xiao, H.J.; Jin, J.H.; Chai, W.G.; Gong, Z.H. Cloning and expression analysis of pepper chlorophyll catabolite reductase gene CaRCCR. Genet. Mol. Res. 2015, 14, 368-379. [CrossRef]

78. Park, S.Y.; Yu, J.W.; Park, J.S.; Li, J.; Yoo, S.C.; Lee, N.Y.; Lee, S.K.; Jeong, S.W.; Seo, H.S.; Koh, H.J.; et al. The senescence-induced staygreen protein regulates chlorophyll degradation. Plant Cell 2007, 19, 1649-1664. [CrossRef]

79. Kusaba, M.; Ito, H.; Morita, R.; Iida, S.; Sato, Y.; Fujimoto, M.; Kawasaki, S.; Tanaka, R.; Hirochika, H.; Nishimura, M. Rice NON-YELLOW COLORING1 is involved in light-harvesting complex II and grana degradation during leaf senescence. Plant Cell 2007, 19, 1362-1375. [CrossRef]

80. Tanaka, R.; Koshino, Y.; Sawa, S.; Ishiguro, S.; Okada, K.; Tanaka, A. Overexpression of chlorophyllide a oxygenase (CAO) enlarges the antenna size of photosystem II in Arabidopsis thaliana. Plant J. 2001, 26, 365-373. [CrossRef]

81. Yang, Y.; Xu, J.; Huang, L.; Leng, Y.; Dai, L.; Rao, Y.; Chen, L.; Wang, Y.; Tu, Z.; Hu, J.; et al. PGL, encoding chlorophyllide a oxygenase 1 , impacts leaf senescence and indirectly affects grain yield and quality in rice. J. Exp. Bot. 2016, 67, 1297-1310. [CrossRef]

82. Wang, X.; Cai, J.; Jiang, D.; Liu, F.; Dai, T.; Cao, W. Pre-anthesis high-temperature acclimation alleviates damage to the flag leaf caused by post-anthesis heat stress in wheat. J. Plant Physiol. 2011, 168, 585-593. [CrossRef] [PubMed]

83. Fan, Y.; Tian, Z.; Yan, Y.; Hu, C.; Abid, M.; Jiang, D.; Ma, C.; Huang, Z.; Dai, T. Winter Night-Warming Improves Post-anthesis Physiological Activities and Sink Strength in Relation to Grain Filling in Winter Wheat (Triticum aestivum L.). Front. Plant Sci. 2017, 8, 992. [CrossRef] [PubMed]

84. Sakuraba, Y.; Park, S.Y.; Paek, N.C. The divergent roles of STAYGREEN (SGR) homologs in chlorophyll degradation. Mol. Cells 2015, 38, 390-395. [CrossRef] [PubMed]

(C) 2020 by the authors. Licensee MDPI, Basel, Switzerland. This article is an open access article distributed under the terms and conditions of the Creative Commons Attribution (CC BY) license (http://creativecommons.org/licenses/by/4.0/). 